\title{
Idaho National Laboratory Cultural Resource Monitoring Report for 2013
}

INL Cultural Resource Management Office

October 2013

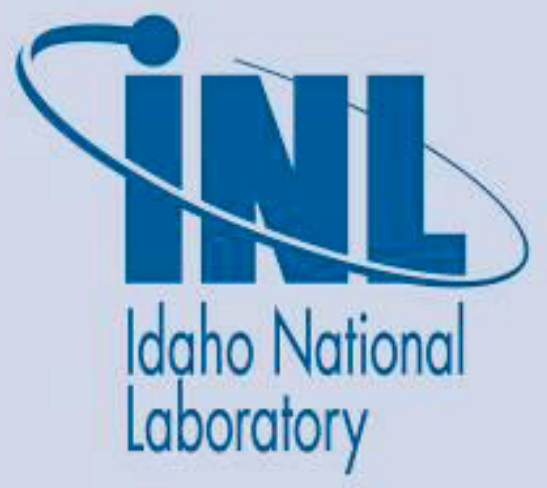

The INL is a U.S. Department of Energy National Laboratory operated by Battelle Energy Alliance 


\section{DISCLAIMER}

This information was prepared as an account of work sponsored by an agency of the U.S. Government. Neither the U.S. Government nor any agency thereof, nor any of their employees, makes any warranty, expressed or implied, or assumes any legal liability or responsibility for the accuracy, completeness, or usefulness, of any information, apparatus, product, or process disclosed, or represents that its use would not infringe privately owned rights. References herein to any specific commercial product, process, or service by trade name, trade mark, manufacturer, or otherwise, does not necessarily constitute or imply its endorsement, recommendation, or favoring by the U.S. Government or any agency thereof. The views and opinions of authors expressed herein do not necessarily state or reflect those of the U.S. Government or any agency thereof. 


\title{
Idaho National Laboratory Cultural Resource Monitoring Report for 2013
}

\author{
INL Cultural Resource Management Office
}

October 2013

Idaho National Laboratory

Energy Resource Recovery and Sustainability

Idaho Falls, Idaho 83415

Prepared for the

U.S. Department of Energy

Office of Nuclear Energy

Under DOE Idaho Operations Office

Contract DE-AC07-05ID14517 



\begin{abstract}
This report describes the cultural resource monitoring activities of the Idaho National Laboratory's (INL) Cultural Resource Management (CRM) Office during 2013. Throughout the year, thirty-eight cultural resource localities were revisited including: two locations with Native American human remains, one of which is also a cave; fourteen additional caves; five prehistoric archaeological sites; four historic archaeological sites; one historic trail; one nuclear resource (Experimental Breeder Reactor-I, a designated National Historic Landmark); and nine historic structures located at the Central Facilities Area. Of the monitored resources, thirty-three were routinely monitored, and five were monitored to assess project compliance with cultural resource recommendations along with the effects of ongoing project activities. On six occasions, ground disturbing activities within the boundaries of the Power Burst Facility/Critical Infrastructure Test Range Complex (PBF/CITRC) were observed by INL CRM staff prepared to respond to any additional finds of Native American human remains. In addition, two resources were visited more than once as part of the routine monitoring schedule or to monitor for additional damage.

Throughout the year, most of the cultural resources monitored had no visual adverse changes resulting in Type 1 determinations. However, Type 2 impacts were noted at eight sites, indicating that although impacts were noted or that a project was operating outside of culturally cleared limitations, cultural resources retained integrity and noted impacts did not threaten National Register eligibility. No new Type 3 or any Type 4 impacts that adversely impacted cultural resources and threatened National Register eligibility were observed at cultural resources monitored in 2013.
\end{abstract}




\section{CONTENTS}

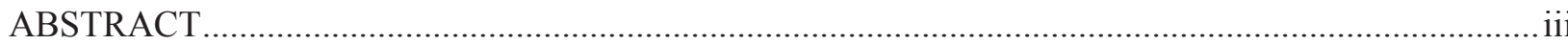

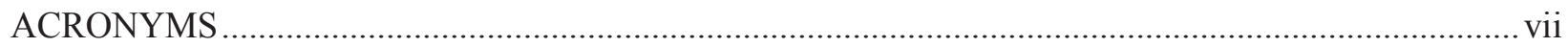

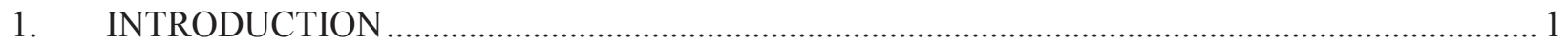

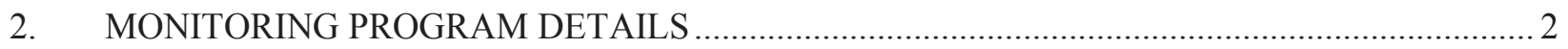

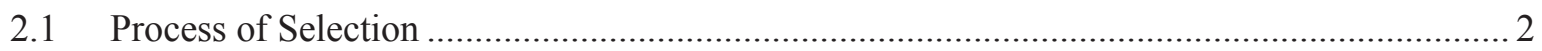

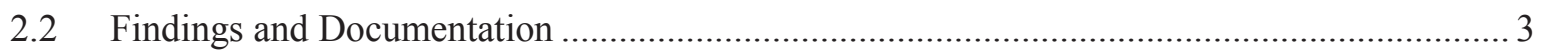

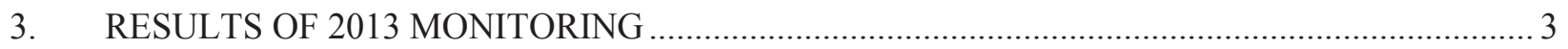

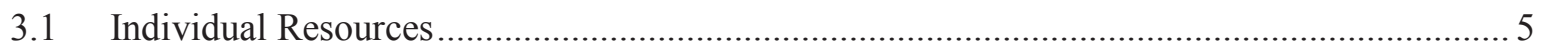

3.1.1 Native American Human Remains ........................................................................... 5

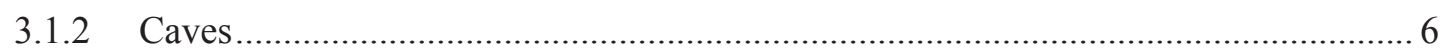

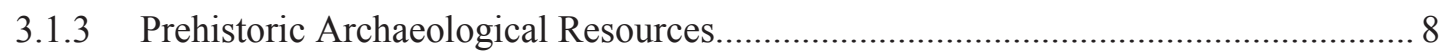

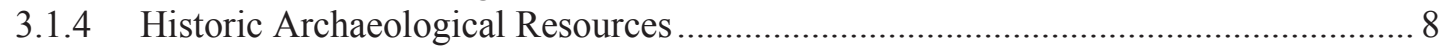

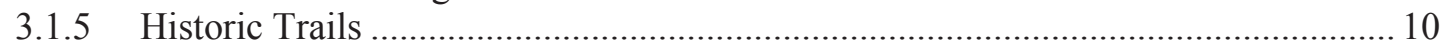

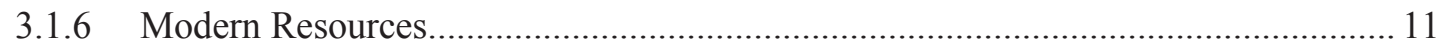

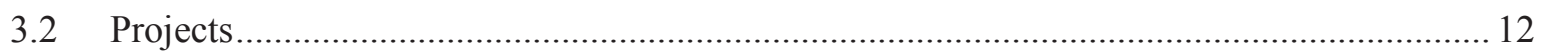

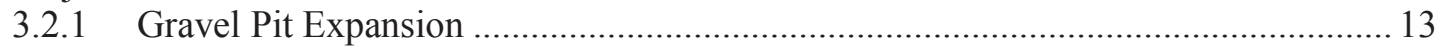

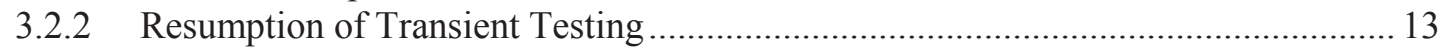

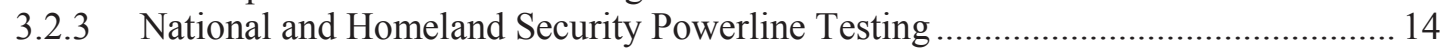

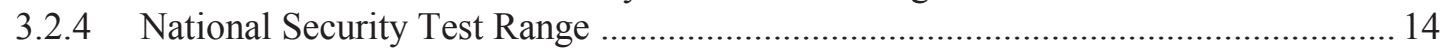

3.2.5 Power Burst Facility/Critical Infrastructure Test Range Complex .......................... 15

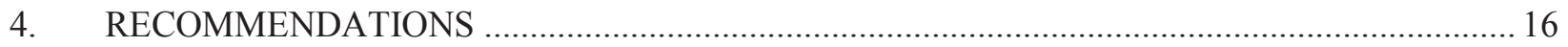

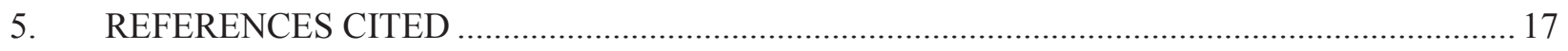

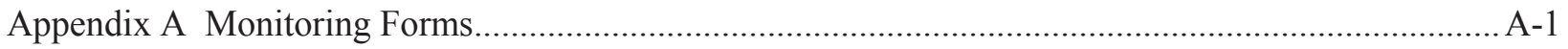

\section{FIGURES}

Figure 1. DOE-ID, Idaho SHPO, ACHP, and BEA representatives visit the Central Facilities Area (Photo courtesy of Don Watts, Idaho SHPO Preservation Planner). ................................... 4

Figure 2. Disturbed remnants of southeast rock wall corner of rock foundation at the Powell

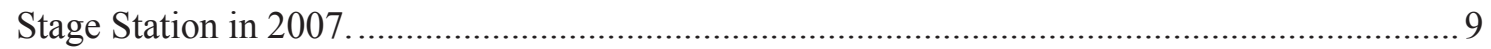

Figure 3. Disturbed remnants of southeast rock wall corner of rock foundation at the Powell Stage Station in 2013 illustrate increased rodent activity..................................................... 9

Figure 4. View of the Proofing Area (CF-633) observation tower and concussion wall showing signs of deterioration (Photo courtesy of Don Watts, Idaho SHPO Preservation

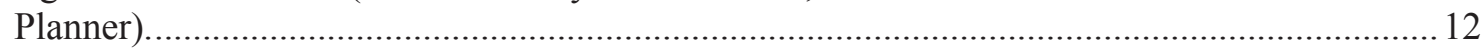

Figure 5. Monitoring of Site 10-BM-223 for the Resumption of Transient Testing Project. .13

Figure 6. Powerline and Road associated with National and Homeland Security Project near Site BEA-08-29-02. 
Figure 7. Removal of gravel/soil berm and old water line pipe at PBF/CITRC monitored by INL CRM staff in 2013

Figure 8. INL CRM Office staff monitoring of ground disturbance at PBF/CITRC. 


\section{ACRONYMS}

\begin{tabular}{ll} 
ARPA & Archaeological Resources Protection Act \\
BEA & Battelle Energy Alliance \\
BM & Bingham (county) \\
BT & Butte (county) \\
BV & Bonneville (county) \\
BLM & Bureau of Land Management \\
CFA & Central Facilities Area \\
CITRC & Critical Infrastructure Test Range Complex \\
CRM & cultural resource management \\
CWI & CH2M Hill-Washington Group Idaho, LLC \\
DOE-ID & Department of Energy, Idaho Operations Office \\
EBR-I & Experimental Breeder Reactor-I \\
ESER & Environmental Surveillance, Education, and Research (program) \\
FY & fiscal year \\
HeTO & Heritage Tribal Office (Shoshone-Bannock Tribes) \\
ICP & Idaho Cleanup Project \\
HTRE & Heat Transfer Reactor Experiment \\
INL & Idaho National Laboratory \\
JF & Jefferson (county) \\
LWP & Laboratory Wide Procedure \\
MCP & Management Control Procedure \\
NEPA & National Environmental Policy Act \\
NHPA & National Historic Preservation Act \\
NRHP & National Register of Historic Places \\
PBF & Power Burst Facility \\
SHPO & State Historic Preservation Office \\
U.S. & United States \\
WERF & Waste Experimental Reduction Facility \\
\hline
\end{tabular}




\section{Idaho National Laboratory Cultural Resource Monitoring Report for 2013}

\section{INTRODUCTION}

The Idaho National Laboratory (INL) is an 890 square mile federal reserve covering portions of five counties on the northeastern edge of the Snake River Plain in southeastern Idaho (Irving 1993, DOE-ID 1996). Lands included within the boundaries of the INL are under the jurisdiction of the U.S. Department of Energy, Idaho Operations Office (DOE-ID) and have been set aside since the 1940s to support many kinds of scientific and engineering research. Currently, four main contractors perform work for DOE-ID at INL. Battelle Energy Alliance (BEA) is the primary Management and Operations contractor, where the INL Cultural Resource Management (CRM) Office is based. CH2MHill/Washington Group (CWI) takes the lead on many cleanup operations related to the Idaho Cleanup Project (ICP), and Idaho Treatment Group leads many activities for the Advanced Mixed Waste Treatment project located within the Radioactive Waste Management Complex. INL's Naval Reactor Facility is under the jurisdiction of the U.S. DOE's Naval Reactors Office and is currently managed and operated by Bechtel-Bettis.

Public access to INL has been restricted since its inception in the 1940s and an active security force patrols the lands and facilities. When encountered, trespassers are removed immediately and can be served with official citations. Largely as a result of long term access restrictions, many cultural resources on the INL are relatively undisturbed. Vandalism is also reduced due to ongoing security patrols and outreach programs that are intended to educate the public and INL employees regarding the importance of leaving artifacts in place and the laws that protect these irreplaceable resources. Despite the patrols and education outreach, over the past decade unauthorized access has been noted at some INL cultural resource sites, particularly those within hunting and grazing easements, or with easy access from the paved roads that bisect or are adjacent to INL boundaries. This may be related to reductions in INL Security programs (i.e. elimination of daily helicopter patrols) and popular national media programs that may encourage artifact collection.

Access restrictions, security patrols, and outreach programs do not prevent all impacts and damage to cultural resources does occur. There are five primary sources of impact:

- Natural processes such as erosion from wind and water or animal burrowing

- Livestock grazing, herding, and associated operations (i.e. watering stations/troughs, feed transport, stock camps)

- Trespassing in highly sensitive areas, unauthorized artifact collection, and advertent and inadvertent damage to fragile cultural resources by members of the public and possibly INL employees and subcontractors unaware of, or indifferent to, penalties associated with these activities

- INL projects that fail to comply with recommendations to protect cultural resources as outlined in Environmental Checklists or other environmental guidance

- Demolition, lack of regular maintenance, or inappropriate preservation treatments for historic structures

Under DOE-ID’s “INL Cultural Resource Management Plan” (DOE-ID 2013a), BEA’s INL CRM Office maintains an ongoing program for monitoring, assessing, and developing strategies to mitigate impacts to cultural resources as a result of these sources of impact. This report provides a summary of the cultural resource monitoring activities completed in 2013. 


\section{MONITORING PROGRAM DETAILS}

A detailed description of the INL CRM Office monitoring program is located in Appendix L of the INL Cultural Resource Management Plan (DOE-ID 2013a). Monitoring enables INL CRM staff to determine if the integrity of known resources is being compromised by natural processes, by unauthorized activities, by demolition, lack of maintenance, or inappropriate preservation measures, or by INL projects. Integrity, not condition, is essential to cultural resources' eligibility for listing on the National Register of Historic Places. As defined by the National Register evaluation criteria, integrity has seven aspects. The aspects include location, design, setting, materials, workmanship, feeling and association (36 CFR 60.4). To be eligible to the National Register, cultural resources must exhibit most, if not all, of the seven aspects. When impacts to cultural resources are identified that may adversely affect integrity, actions to avert further deterioration can be initiated and federal stewardship responsibilities are fulfilled.

\subsection{Process of Selection}

Specific cultural resources are chosen for monitoring based on INL CRM Office priorities as well as feedback from DOE-ID, the Shoshone-Bannock Heritage Tribal Office (HeTO), and INL stakeholders. The INL CRM archives, which include documentation of over 2,700 archaeological resources and nearly 300 historic architectural properties, are also consulted for appropriate candidates for yearly monitoring. Both DOE-ID and the HeTO staff are often directly involved in fieldwork during the monitoring activities and INL project managers and other stakeholders, such as the Idaho State Historic Preservation Office (SHPO), also participate occasionally. Certain resources, like Middle Butte, Prickly, and Aviators Caves, sensitive localities inside the Power Burst Facility (PBF, now Critical Infrastructure Test Range Complex (CITRC), the Experimental Breeder Reactor-I (EBR-I) National Historic Landmark, are monitored every year. Others, such as historic homesteads, some prehistoric archaeological sites, and important World War II structures are also visited routinely because of their location in highly visible or near public accessible areas where trespassing and adverse impacts have been documented in the past. Each year INL CRM staff also conducts surveillance of resources in a wide variety of settings to address ongoing research interests and the overall focus of INL construction and project activities.

Monitoring of INL projects is completed under direct project funding and may be required as part of an INL Environmental Checklist or other environmental guidance. Project-specific monitoring is also routinely completed in the sandy aeolian soils inside the boundaries of the PBF/CITRC area, where Native American human remains have been discovered in both primary and secondary (i.e. disturbed) contexts. Cultural resource monitoring of projects that involve soil disturbance within this facility complex is required by company procedures (e.g. BEA's LWP-8000 and CWI's MCP-3480). This level of cultural resource oversight ensures that any new discoveries of human remains will be managed appropriately.

Forms developed by INL CRM Office staff are completed for every cultural resource monitored. Hard-copy and electronic versions of these documents are maintained in the INL CRM files and are reproduced for 2013 in Appendix A of this report. INL CRM staff may also create and archive a variety of photographs to document monitoring efforts. A few of these electronic images are reproduced here to illustrate parts of the narrative. 


\subsection{Findings and Documentation}

Under the INL CRM monitoring program, there are four possible findings for given monitoring, based on the level of disturbance noted:

- Type 1: no visible changes to a cultural resource and/or a project is operating within the limits of cultural resource clearance recommendations

- Type 2: impacts are noted but do not threaten the integrity and National Register eligibility of a cultural resource and/or a project is operating outside of culturally cleared limitations

- Type 3: impacts are noted that threaten the integrity and National Register eligibility of a cultural resource and/or a project has been operating outside of culturally cleared limitations and impacts to cultural resources have occurred

- Type 4: impacts that threaten the integrity and National Register eligibility of a cultural resource are occurring during the monitoring visit, justifying the use of the INL Stop Work Authority (LWP14002, MCP-553)

If Type 2, 3, or 4 impacts are documented during monitoring, notifications are made to project managers, the DOE-ID cultural resources coordinator, and various other parties, as appropriate and according to the nature and severity of the disturbance. Typically, Type 2 impacts can be corrected by CRM Office personnel or with the cooperation of INL project managers, security personnel, and/or landlord organizations. In these instances, the impacts are only reported in summary fashion in year-end reports. Some Type 2 and all Type 3 or 4 impacts prompt formal investigations initiated by the INL CRM Office. INL project managers, security, and/or landlord organizations, DOE-ID, and ShoshoneBannock tribal representatives may also participate in these investigations.

Results of all monitoring and, if available, formal impact investigations' reports are summarized annually in a year-end report to DOE-ID (cf. INL CRM 2013) and also appear in a higher level summary of INL CRM Office yearly activities that is sent to DOE-ID and other parties such as the Idaho State Historic Preservation Office, the Shoshone-Bannock Tribes, and interested stakeholders. In 2013, the annual summary was included in the "INL Site Environmental Report Calendar Year 2012" (DOE-ID 2013b).

\section{RESULTS OF 2013 MONITORING}

In 2013, forty-two monitoring forms (Appendix A) were completed throughout the year to document individual site visits, to assess project compliance with cultural resource recommendations, to confirm the locations of specific cultural resources in relation to project activities, and to document observation of ground disturbing activities in sensitive areas. Representatives from INL projects, DOE-ID, the Idaho SHPO, and the Shoshone-Bannock Tribe's HeTO participated in several of the trips in 2013 (Figure 1). The INL CRM staff also took the opportunity to visit select INL caves, sometimes for the first time. This opportunity was offered during the winter months by researchers associated with the INL Site Environmental Surveillance, Education, and Research program (ESER) administered by GonzalesStoller Surveillance (GSS) in conjunction with their ongoing bat research.. Combining archeological monitoring with the bat research project served to limit the number of cave entries in the interest of protecting sensitive biological as well as cultural resources. As a result of the multiple cave entries completed in 2013, INL CRM staff have added significant observations to the INL Site cave inventory and established baselines for future monitoring at caves that had not been visited previously. 


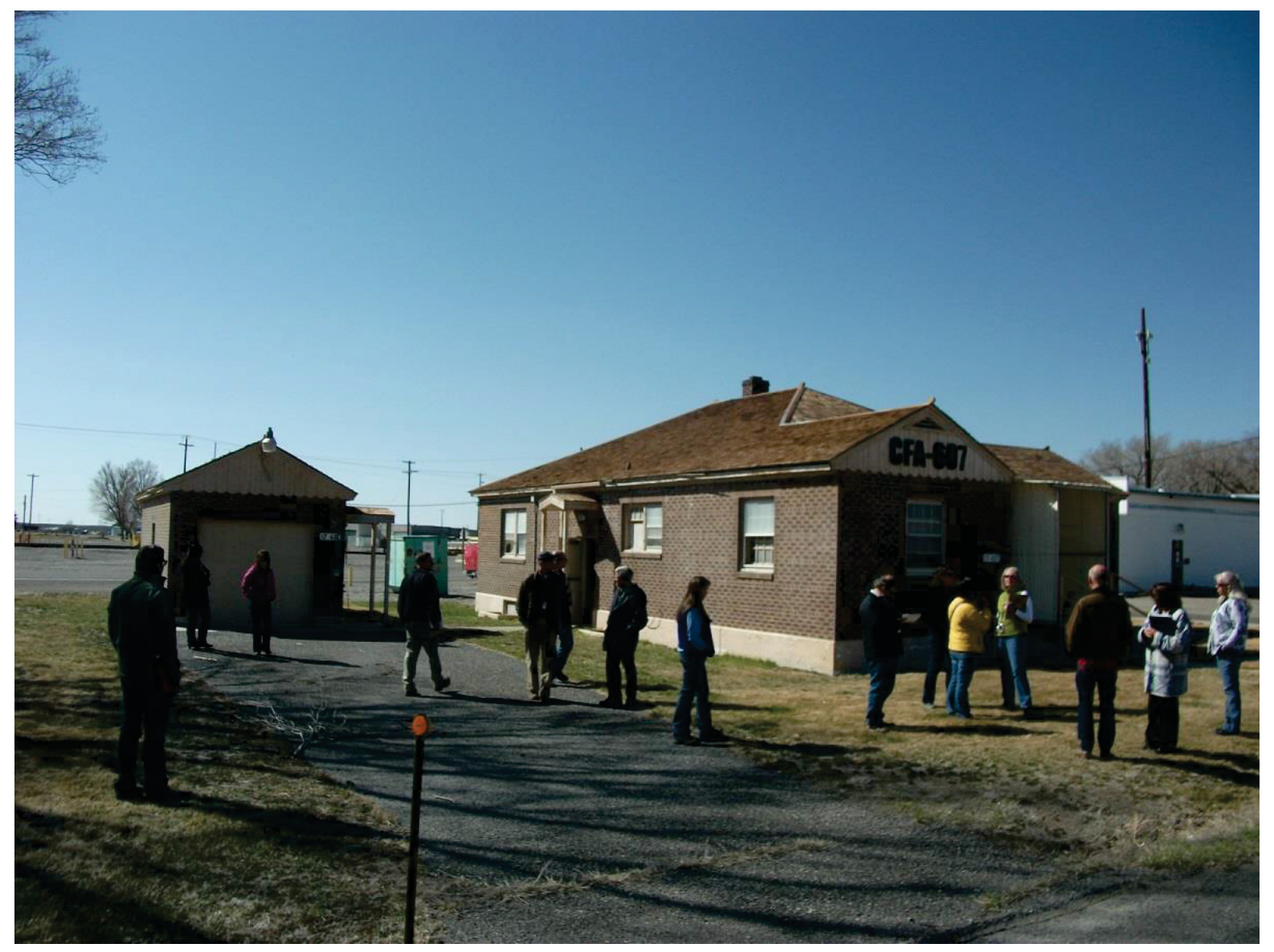

Figure 1. DOE-ID, Idaho SHPO, ACHP, and BEA representatives visit the Central Facilities Area (Photo courtesy of Don Watts, Idaho SHPO Preservation Planner).

Throughout the year, most of the cultural resources monitored had no visual adverse changes resulting in Type 1 determinations. However, Type 2 impacts were noted at eight sites. In all of these cases, although impacts were noted or documentation was made of INL projects operating outside of culturally cleared limitations, cultural resources retained integrity and noted impacts did not threaten National Register eligibility. No new Type 3 or any Type 4 impacts that adversely impacted cultural resources and threatened National Register eligibility were observed at the cultural resource locations monitored in 2013.

In an effort to address select recurring Type 2 impacts and Type 3 impacts to prehistoric archaeological sites documented in previous years, INL CRM staff continued to interact with DOE-ID Physical Security and U.S. federal agents experienced in enforcing the Archaeological Resource Protection Act (ARPA) toward successfully prosecuting individuals who have violated the law. It is anticipated that interaction and cooperation between the federal agents, DOE-ID Security, and the INL CRM Office will be ongoing through 2014 and beyond, leading to more effective tools to identify unauthorized visitors and protections for sensitive INL cultural resources. 


\subsection{Individual Resources}

In 2013, INL CRM staff conducted official surveillance of thirty-eight individual cultural resources including: two locations with Native American human remains, one of which is a cave, fourteen additional caves, five prehistoric archaeological sites, four historical archaeological sites, one historic trail, the Experimental Breeder Reactor-I National Historic Landmark, and nine historic structures located at the Central Facilities Area. As noted in the discussions to follow, two resources were visited on more than one occasion. Forms that document individual observations and recommendations are included in Appendix A.

\subsubsection{Native American Human Remains}

Two INL locations that include sensitive Native American human remains are visited at least once a year for monitoring and stabilization, as necessary. These are the Waste Experimental Reduction Facility (WERF) remains (10-BT-2046), located within the PBF-CITRC area, and Prickly Cave (10-BT-2037).

\subsubsection{WERF}

The WERF location (10-BT-2046) consists of sensitive human remains that were found eroding from the floor surface of an artificial drainage basin in FY 1996. Investigations confirmed that these sensitive materials were resting in their original position and in consultation with the Shoshone-Bannock Tribes steps were taken to secure them and prevent any future disturbance. Today these remains are secure beneath four truckloads of clean soil. The area is monitored yearly with the assistance of HeTO representatives. In 2013, rodent activity in the area seemed to have ceased but it was noted that the fence surrounding the burial was starting to sag and would need some maintenance in the future.

\subsubsection{Prickly Cave}

Prickly Cave (10-BT-2037) is a relatively small lava tube cave with a correspondingly small opening that is flush with the exterior ground surface. Cultural materials located on the cave exterior are characterized by a light and unremarkable scatter of lithic debris along with a few stone tools. The cave interior however, houses sensitive human remains along with various perishable (wood, bone) tools. The human remains consist of skeletal elements originally found in the cave as well as some that were repatriated at tribal request to Prickly Cave from another INL location. The 2013 monitoring found no signs of surface disturbance to artifacts surrounding the cave entrance nor were signs of unauthorized visitation observed. As a result, HeTO director Carolyn Smith determined that entry into the cave was unnecessary.

In 2013, no new or adverse impacts were observed at either of these locations and measures to stabilize the sensitive remains appear to remain adequate. Natural forces such as erosion and burrowing animals remain the primary agents of the Type 2 impacts that are occasionally observed in these areas and both warrant continued surveillance and intervention, as necessary. 


\subsubsection{Caves}

Lava tube caves are numerous on the basaltic landscape of the northeastern Snake River Plain and within the boundaries of the INL Site. Cultural materials present within INL caves are fragile, unique, irreplaceable, scientifically and culturally important, and of great significance to the Shoshone-Bannock Tribes. One cave located on the INL Site (Aviators Cave), is listed on the National Register of Historic Places in recognition of these important values and other INL caves remain eligible for this distinction.

INL caves also include a number of sensitive biological resources and many provide critical winter habitat for hibernating bats and rattlesnakes. Recently, several bat species have become endangered due to heavy mortality from White Nose Syndrome, a bat-specific disease that is moving steadily westward from the eastern U. S. and decimating bat populations along the way. Many caves across the U. S. have been closed in an effort to prevent the spread of this disease and the U.S. Fish and Wildlife Service has recommended procedures for access and decontamination in caves that remain open. At the INL Site, DOE-ID now allows cave entry only under the guidance of approved permits and plans and strict decontamination protocols. In 2013, INL CRM Office staff finalized a Laboratory-Wide Procedure (LWP) for Cave Protection and Access at the INL Site (LWP-8500).

Due to their high cultural and tribal sensitivity, a variety of INL caves are monitored by the INL CRM Office every year and some locations are visited more than once. In 2013, DOE-ID issued a permit for this routine cultural resource monitoring in and around INL caves. INL CRM Office staff and HeTO representatives visited three culturally important caves late in 2012 and in 2013: Prickly Cave, Middle Butte Cave, and Aviators Cave. Observations recorded for the areas surrounding these caves are included in forms provided in Appendix A. However, several factors led INL CRM staff and HeTO representatives to agree that the routine cave entries were not necessary during these visits. In this context, none of the caves exhibited any evidence of unauthorized activity or potential disturbances around their entrances, personnel were committed to minimizing cave entry as much as possible to protect sensitive bats, and many caves had been previously entered and their conditions monitored during INL CRM Office and HeTO participation in wintertime bat research projects.

In an effort to better understand vulnerable bat populations on the INL Site, DOE-ID is sponsoring biological research through the INL Site Environmental Surveillance, Education, and Research program (ESER) administered by Gonzales-Stoller Surveillance (GSS). In 2013, cave entry permits were awarded to support this research in 14 INL caves including: East Boundary Cave, North Tower-Earl Cave, Lek Cave, Jeep Trail Cave, Link Sausage Cave, Travois Cave, Middle Butte Cave, College Cave, Moonshiners Cave, Jensens Cave, Rattlesnake Cave, Lost Cave, North Tower-Wakenhut Cave, and Aviators Cave. Activities included winter counts of hibernating bats in all 14 of the caves and fall mist-netting at Middle Butte Cave.

INL CRM Office staff and HeTO representatives participated in the bat research-related cave entries to ensure no sensitive cultural resources were impacted by the work, to learn more about bats and other sensitive biological resources, and to provide assistance when possible. In recognition of the need to minimize all cave entries to protect bats, the cultural resource participants also sought to take advantage of an opportunity to collect a quick baseline assessment of several caves that have not been fully investigated for cultural resource sensitivity. Although bat research clearly remained the primary focus of all cave entries, the thorough searches of cave interiors required by the bat research also allowed for quick observations of cultural materials present, the overall archaeological potential of each cave, and any impacts to the cultural materials observed. 
Monitors concluded that all of the caves exhibit some potential for archaeological deposits from prehistoric and historic times. Tribal interest is also significant for all. All of the caves also appeared to be relatively undisturbed, although several caves did contain old evidence of shallow excavations that may be attributable to animals or possible looting in the past. Recent footprints were observed in East Boundary Cave, located along the outer boundary of the INL Site, probably indicating unauthorized visitation within the past year or two. This observation constitutes a Type 2 finding for purposes of this report. However, the National Register eligibility of the cave and its sensitive historic artifacts does not appear to be threatened. Since the cave is located in a remote area along the INL boundary, unauthorized access remains a threat and additional visits may be justified to ensure that no adverse impacts develop. No recent evidence of looting or other adverse impacts was observed in any cave during the bat monitoring research visits.

Appendix A includes forms documenting INL CRM and HeTO observations during these visits. No impacts occurred as a result of the bat research activities and ESER GSS personnel demonstrated a commitment to avoiding any activities that would cause cultural resource impacts. The visits also generally confirmed that INL caves remain largely unaffected by modern disturbances.

\subsubsection{Middle Butte Cave}

Middle Butte Cave (10-BM-34) is a large lava tube, with a cavernous opening and a subterranean extent of nearly 0.4 mile. Artifacts and paintings on the walls, both ancient and modern, indicate that the Cave has been a destination for human populations for a very long time. The Cave is of particular significance to the Shoshone-Bannock Tribes and DOE-ID has recognized their interests in a Memorandum of Agreement that assures continued access for ceremonial, cultural, and educational activities (DOE-ID 1994).

Restrictions on access to Middle Butte Cave have been in place for decades but the cave's location appears on topographical maps of the area and unauthorized visitation continues to be a problem. In the past, vandals have fired bullets into signs at the area, use the area for target practice, and continue to drive around existing barriers.

For several years, Middle Butte Cave has been part of an ongoing bat study and is therefore visited at least once a month by ESER GSS research personnel for data collection. INL CRM staff participated in 2013 winter bat counts and fall mist-netting research activities to monitor for cultural resource impacts. In 2013 Middle Butte Cave was also monitored once with HeTO director, Carolyn Smith. Based on observations made around the cave entrance, it was determined that no unauthorized visitation had occurred in 2013 and that entry into the cave was not necessary. However, there was evidence that a vehicle had been driving around the gate entrance. GSS research personnel were contacted and advised to park vehicles on the main road outside of the gate and walk to the cave.

\subsubsection{Aviators Cave}

Aviators Cave (10-BT-1582) is listed on the National Register of Historic Places. It is another large INL lava tube with extensive evidence of prehistoric use and contemporary significance to the ShoshoneBannock Tribes. It is monitored for impacts at least once a year. Tribal participation in annual monitoring has become increasingly important since 2002, because at this time tribal representatives returned an especially sensitive item to an area in the Cave that is known only to them. On yearly visits, they inform INL CRM staff of any changes. There have been no official reports of disturbances to this item noted to date. However, since FY 2000, when a large range fire burned through the area, unauthorized visitation has increased. Incursions were initially via 4-wheel drive vehicle in FY 2000, but since vegetation has returned, trespassers have arrived on foot. Small concentrations of artifacts left in "discard" piles near the Cave entrance represent the unauthorized activities. These activities have been reported in previous years as Type 3 impacts to DOE-ID and investigations are ongoing. 
Monitoring of the surface area surrounding Aviators Cave was minimized in 2013 in order to reduce overall visitation to this sensitive cultural resource. Surface conditions were assessed late in September of 2012 and in mid-October of 2013 by INL CRM Office and HeTO representatives, and no significant impacts were documented. In order to minimize cave entries to protect sensitive bats, the interior of the cave was monitored as part of a bat hibernation survey and count in 2013. No impacts to sensitive cultural materials inside the cave were documented during this visit. Given the high level of cultural sensitivity of Aviators Cave, past evidence of unauthorized visitation, and high interest and concomitant increased visitation to the cave for bat-related research, monitoring will continue at Aviators Cave through 2014.

\subsubsection{Prehistoric Archaeological Resources}

There are thousands of prehistoric archaeological sites within INL boundaries, ranging in age from more than 13,000 to 150 years old. The great antiquity and excellent condition of many of these sites is notable and provides justification for routine visitation and care to prevent adverse impacts. In 2013, INL CRM staff monitored the rock walls and dense artifact scatter associated with the campsite known as "Hellofasite" (10-JF-88). No new impacts from the nearby National Security Test Range were observed at the site. Federal agents continue an investigation of vandalism observed at the site in FY 2011 and FY 2012 (unauthorized artifact removal, heavy equipment travel, mowing). In 2013, surface soils at the site continued to be influenced by wind, alternately exposing and covering the artifacts that remain on the surface. No new evidence of looting or human-caused disturbance was apparent.

Additional prehistoric archaeological sites were also monitored in 2013 to assess impacts in relation to ongoing INL project activities. Section 3.2 provides additional detail on all project-specific monitoring.

\subsubsection{Historic Archaeological Resources}

During the period from 1884 to roughly 1930, hundreds of hopeful settlers filed homestead claims on lands that would eventually be designated as the INL. Federal laws that encouraged settlement of western deserts were often catalysts for these activities and, in the arid INL region, the Desert Land Act of 1877, Carey Land Act of 1894 and the Desert Reclamation Act of 1902 were especially influential. Many types of historic archaeological sites remain from this time, including homesteads, stage and freighting stations, trails, town sites and railroad sidings, ditches and canals, and the construction camps that were often necessary to build and support them. INL CRM Office staff monitoring of several of these historic archaeological resources is routine. In 2013, two historic stage stations and two homesteads were visited.

\subsubsection{Stage Stations}

The Powell Stage Station (10-BT-2194) is named after its founder, George Washington Powell, and operated in the late 1800s near the Big Lost River. Remnants of the Station include a basalt foundation and partial wall structure (Figure 2). Evidence of other structures (i.e., bridge, outbuildings) is also extant. In FY 2011 and 2012, Type 2 impacts were noted as a result of animal burrowing in the southeast and southwest corners of the rock foundation. During 2013 monitoring, it was determined that animal burrowing activity is increasing (Figure 3). Therefore, INL CRM staff will work with ESER biologists for possible solutions to discourage this Type 2 activity. 


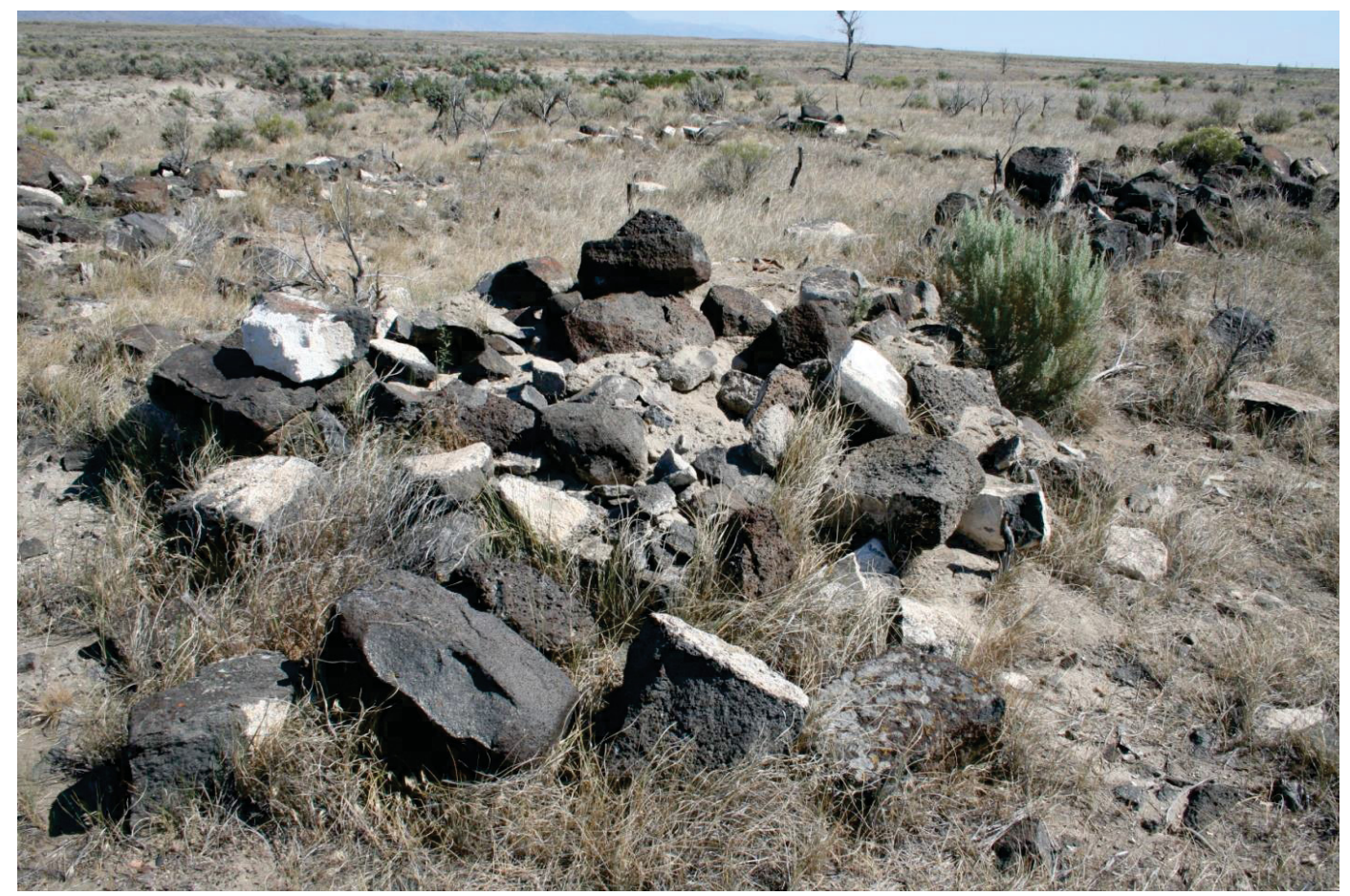

Figure 2. Disturbed remnants of southeast rock wall corner of rock foundation at the Powell Stage Station in 2007.

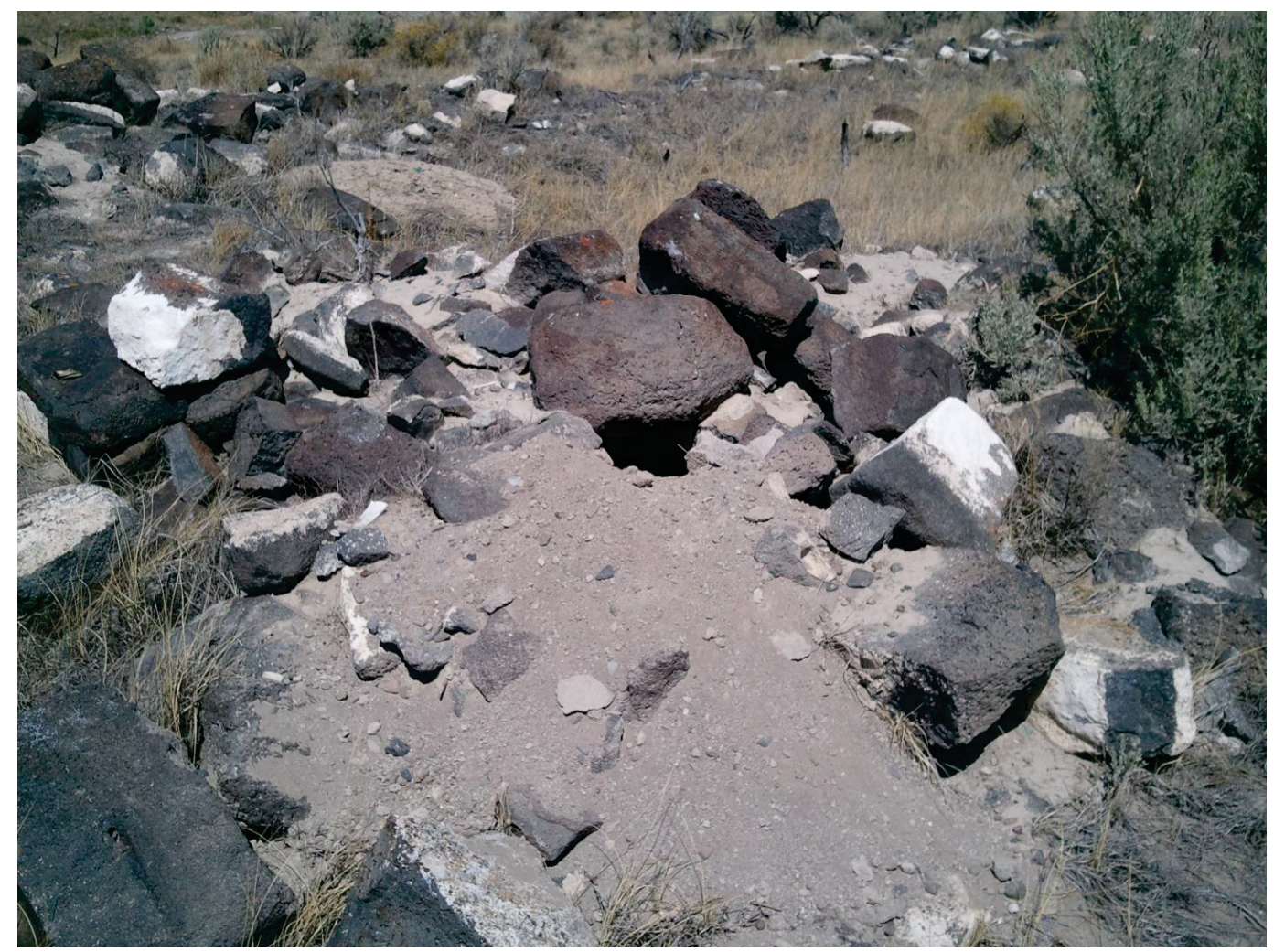

Figure 3. Disturbed remnants of southeast rock wall corner of rock foundation at the Powell Stage Station in 2013 illustrate increased rodent activity. 
The Birch Creek Stage Station (10-BT-2362), also known as the Reno Homestead, is another site that is routinely monitored due to its remote location and close proximity to public land. In the past it has been referred to as a stage station based on survey documentation. However in 2011, descendants of the Frank Jerome Reno family contacted the INL CRM Office and presented family photographs along with additional documentation establishing it later as the Reno Homestead. Evidence of both uses of this area exists. For clarity, INL CRM Office staff chose to discuss the site in this section of the report but recognize its importance as a homestead, as well as a stage station. During 2013, it was determined that unlike in previous years, there was no new evidence of livestock grazing or sheepherder camps. No new impacts were noted in 2013.

\subsubsection{Historic Homesteads}

In 2013, two historic homesteads were visited by INL CRM staff; the Richards Homestead (10-BT2358) and the Kuharski homestead (10-CL-1054).

\subsection{Richards Homestead}

The Richards Homestead (10-BT-2358) was occupied from 1884 to approximately 1902. The site is named after John Richards, a British immigrant who is known to have filed the first water rights on the INL. Along with his wife Evelyn, he raised eight children on their homestead. The site consists of several basalt foundations (house, sheds and barns), two possible dugout features, fence posts, hand dug ditches, a small reservoir, field scars and an extensive trash scatter. Monitoring in 2013 determined that the site had been grazed by both cattle and sheep depleting the area of vegetation and somewhat churning the soils. Vehicle tracks were also noted off road over the site, but no damage was observedd.

Weathering continues to affect the condition but not the integrity of this site. The site will continue to be monitored annually.

\subsection{Kuharski Homestead}

The Kuharski Homestead (10-CL-1054) is a ca. 1885 site named after Stanovich Kuharski, a German immigrant. The site consists of a basalt foundation, a suspected handmade brick forge, fence posts, field scars and an extensive trash scatter. Weathering continues to affect the condition but not the integrity of the site and its proximity to public lands may result in unauthorized visitation. In 2013, no new impacts were noted and previously observed and reported animal burrowing has subsided. Monitoring will continue in FY 2014.

\subsubsection{Historic Trails}

INL lands are crossed by a multitude of unimproved trails, many dating to historic times around the turn of the $20^{\text {th }}$ Century. These trails were important links between communities along the Snake River (e.g. Blackfoot and Eagle Rock/Idaho Falls) and those located in mountain valleys to the west and north (e.g. Mackay, Howe, Arco). People, goods, and stock passed freely along the established paths and encouraged economic growth in the region. Continued sporadic travel on the trails today by modern vehicles ensures that they remain visible on the contemporary landscape. However, wildland fires, heavy vehicle and stock traffic and inappropriate maintenance can adversely impact the trails, destroy their context and setting, and adversely impact archaeological resources nearby.

Goodale's Cutoff (also known at T-1) is a section of the Oregon Trail, which is monitored because of its occasional heavy use by cattle ranchers. The section of Goodale's Cutoff that crosses the INL is approximately eight miles in length and remains one of the most pristine sections of the trail. Monitoring in 2013 determined that the trail remains in excellent condition with moderate use and no new impacts. Monitoring will continue in FY 2014. 


\subsubsection{Modern Resources}

Historic resources constructed during INL's period of historic significance (1942-1970) provide an important material record of the development of what is now the INL. In 2013, in addition to a routine visit to Experimental Breeder Reactor I (EBR I) monitoring of properties associated with World War II was also conducted.

\subsubsection{Experimental Breeder Reactor-I}

Experimental Breeder Reactor-I (EBR-601) is INL's single designated National Historic Landmark, recognized as such because of its association with the early development of nuclear power and reactor technology. It is the only INL facility open to the public on a seasonal basis (Memorial Day through Labor Day, annually). In past years, EBR-I has benefited from a "Save America's Treasures" grant, which supported updated exhibits to enhance the Visitors Center and addressed some preservation issues such as brick and mortar restoration (Braun 2006). Nuclear artifacts exhibited at the site include two Heat Transfer Reactor Experiment (HTRE) airplane engines and the specialized locomotive used to position them during experiments in the 1950s. These resources are eligible for nomination to the National Register.

In 2013, monitoring of the EBR-I reactor facility and associated guardhouse was completed. As was reported in previous years, an inadequate water drainage system continues to threaten the integrity of bricks and mortar on the EBR-I building and the guardhouse continues to lack basic maintenance. If these Type 2 impacts are not corrected, Type 3 impacts are likely to result. INL CRM staff will continue to work with DOE-ID and INL landlord organizations in 2014 to address ongoing maintenance and preservation of these important and highly visible public resources.

\subsubsection{Naval Proving Ground}

During World War II, approximately 270,000 acres within what is now the interior area of the INL was used as a naval ordnance proving ground. Several structures were built to accommodate residents and to provide an area to test fire a wide variety of ordnance including the large guns used on the Pacific Fleet. The structures were reused when the Atomic Energy Commission established the National Reactor Test Station on what is now the INL Site in 1949. Although many of them have been removed, some of the structures still exist and are eligible for listing on the National Register of Historic Places. They include buildings: CF-606, CF-607, CF-613, CF-632, CF-633 (Figure 4), CF-637, CF-638, CF-642, and CF-651 along with various other associated structures (i.e., gun abutments, roads, gantry crane).

In 2013, monitoring was completed of the Central Facilities Area World War II buildings and associated structures. Vacancy and lack of basic maintenance of all structures except the active CF-642 and CF-651 pump houses and CF-637 and CF-638 ammunition bunkers has resulted in impacts such as spalling concrete, rotting trim, cracks, and broken windows. The impacts from neglect affect the structures' condition; however, their integrity is still excellent. The properties have been slated for removal and in 2013, the INL CRM staff worked with DOE-ID, BEA facility managers, the DOE-HQ Federal Preservation Officer, Idaho State Historic Preservation Officer (SHPO), and the Advisory Council on Historic Preservation (ACHP) and identified measures to mitigate the adverse impacts that removal will have on these historic INL properties and the INL World War II landscape. Consultation between the parties is ongoing and a Memorandum of Agreement outlining mitigation measures is expected to be signed and implemented in 2014. 


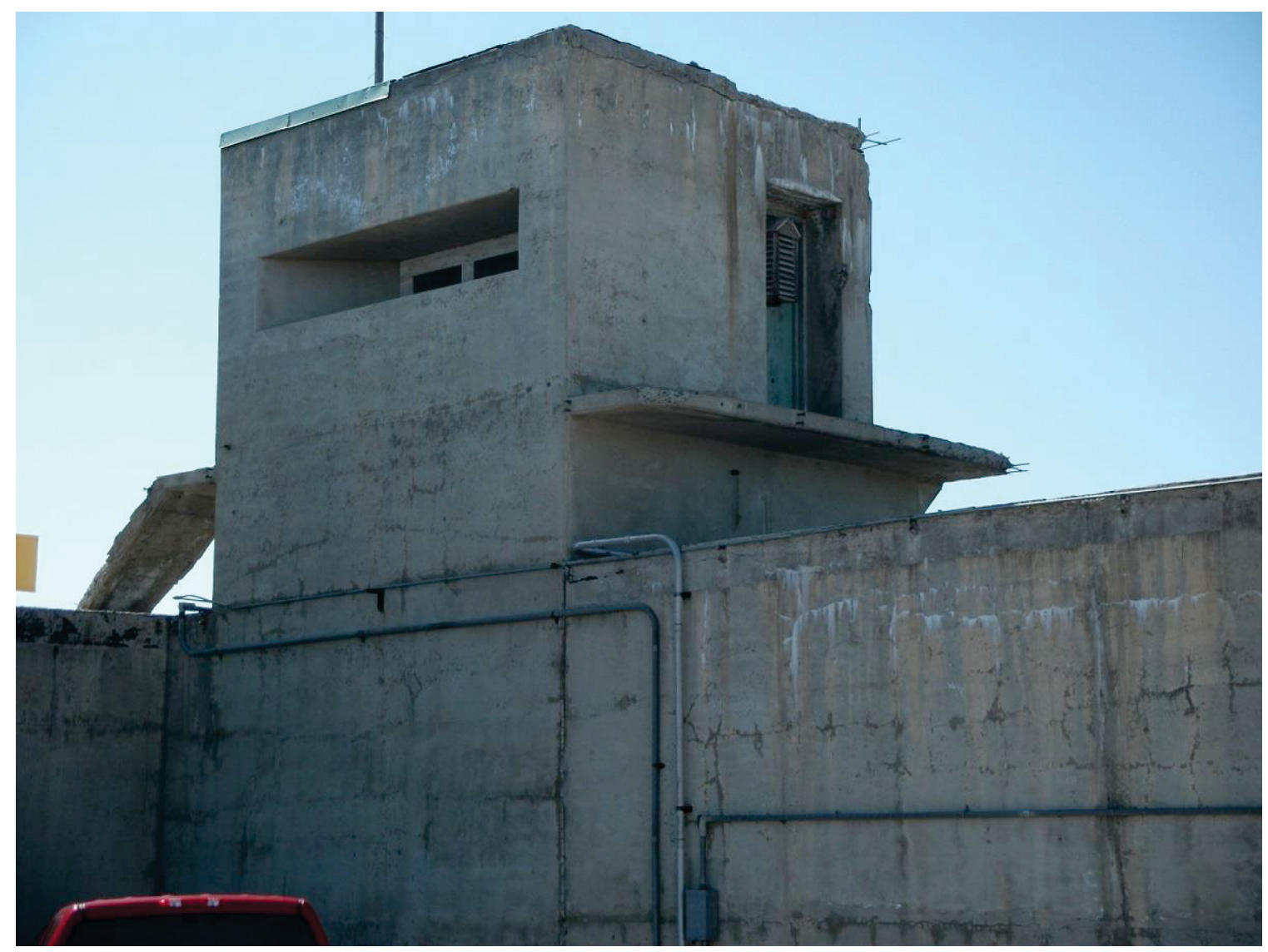

Figure 4. View of the Proofing Area (CF-633) observation tower and concussion wall showing signs of deterioration (Photo courtesy of Don Watts, Idaho SHPO Preservation Planner).

\subsection{Projects}

Project-specific cultural resources monitoring is conducted at INL to meet three distinct purposes. In one situation, previously recorded cultural resources may be revisited to assess current conditions and assist in the development of recommendations for addressing potential impacts during future project activities. In 2013, two previously recorded archaeological resources located near proposed new projects (Gravel Pit Expansion and Resumption of Transient Testing) were revisited and assessed for this purpose. In a second type of project monitoring, INL projects are audited for compliance with cultural resource recommendations made during the INL environmental review process. In this context, two ongoing INL projects (National and Homeland Security Powerline Testing and National Security Test Range) were monitored in 2013. Finally, in a third type of project monitoring, ground disturbance associated with INL project activities in archaeologically sensitive areas is directly observed by INL CRM Office staff. This type of project monitoring is frequently done when ground disturbance occurs within the boundaries of the Power Burst Facility/Critical Infrastructure Test Range Complex (PBF/CITRC), where sensitive cultural materials were unexpectedly uncovered in the 1990s. In 2013, ground disturbance was observed on six occasions for three new projects at PBF/CITRC.

Short discussions of the project-related cultural resources monitoring activities that were completed in 2013 are included in the Sections to follow and forms that document all 2013 observations are provided in Appendix A. Monitoring forms completed for observation of ground disturbance at the PBF/CITRC area may include multiple visits on a single form. 


\subsubsection{Gravel Pit Expansion}

The Monroe Blvd gravel pit is an important source of pit run gravel for many INL projects. Westward expansion of the pit occurs periodically within a large 80 -acre area that was originally surveyed for archaeological resources in 1989 and 1994 (DOE-ID 2013a). In 2013, a proposed expansion of the pit was evaluated for potential impacts to a previously recorded prehistoric archaeological site, 10-BT-1996, located approximately 125 meters from the current edge of the active pit. This small prehistoric campsite appeared to be little changed from its original recording in 1994. INL CRM Office staff will continue to work with project personnel in FY 2014 to ensure that this site is not affected by gravel pit operations.

\subsubsection{Resumption of Transient Testing}

DOE is considering alternatives for reuse and modification of existing nuclear reactor facilities to support a renewed transient testing program (DOE-ID 2013c). One alternative under consideration involves restarting the Transient Reactor Test reactor (TREAT) located at the Materials and Fuels Complex (MFC) on the INL. In 2013, INL CRM Office staff and HeTO representatives evaluated the potential impacts to historic architectural properties and archaeological sites associated with this project (Pace and Williams 2013). Investigators concluded that the proposed reuse and continued ongoing use of historic architectural properties during the project is consistent with original missions related to nuclear reactor testing and is expected to result in no adverse effects to their historic significance.

For archaeological resources, ground disturbance associated with the project is unlikely to have any direct impact on one previously recorded prehistoric archaeological site, 10-BM-223 located nearby. Monitoring of this small site in 2013 demonstrated that range fires and subsequent wind erosion have had substantial limiting effects on artifact visibility, but have not caused adverse impacts. Indeed, with only a few artifacts visible at the ground surface in 2013, it appears that aeolian sediment has covered much of the original site and this is providing some protection for the artifacts located there (Figure 5). Impacts from the proposed resumption of facility operations at TREAT are unlikely, but monitoring will continue.

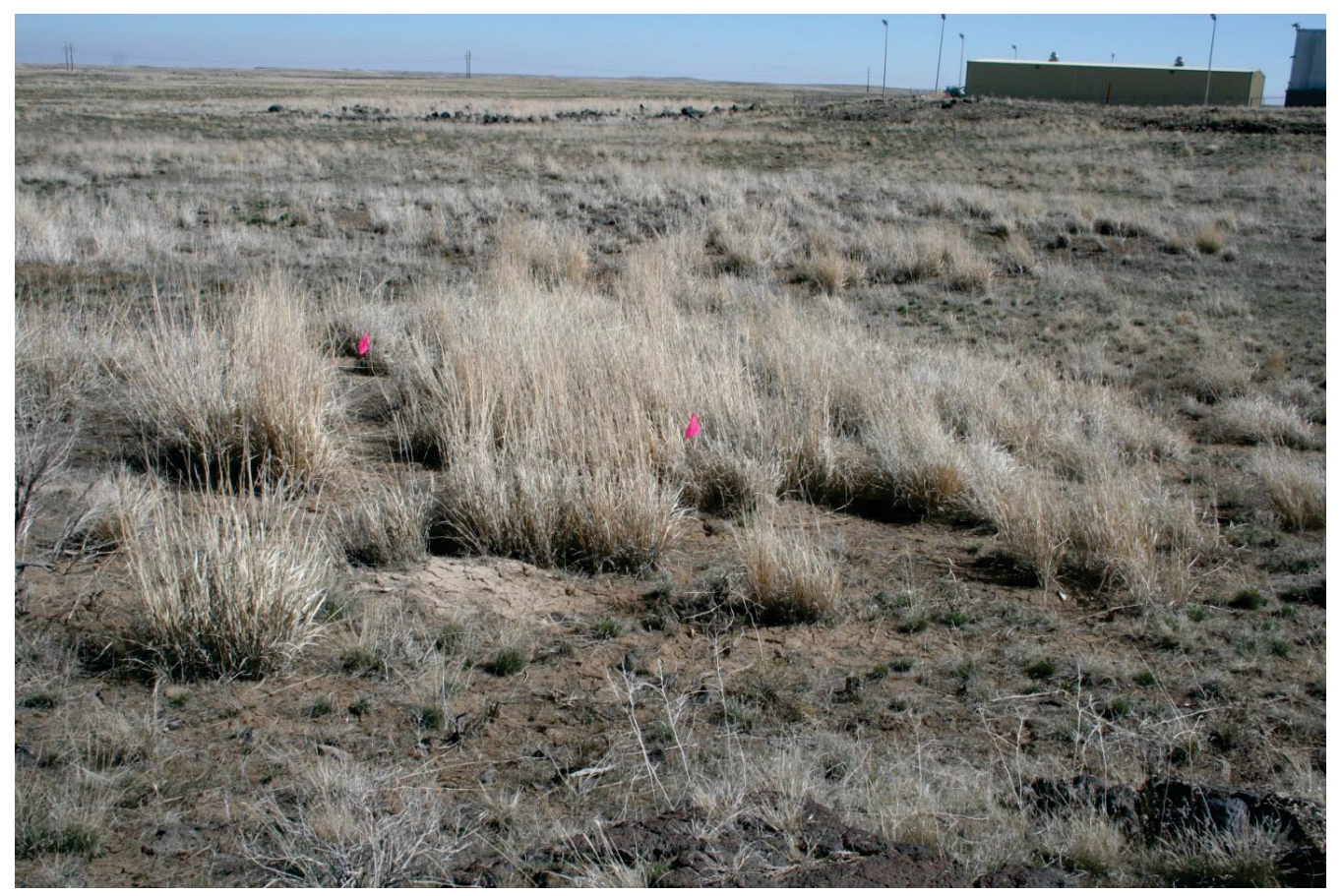

Figure 5. Monitoring of Site 10-BM-223 for the Resumption of Transient Testing Project. 


\subsubsection{National and Homeland Security Powerline Testing}

The Powerline Testing project within INL's National and Homeland Security program operates a unique network designed to research and test a variety of cellular, mobile, wired, and other technologies. In 2013, cultural resources monitoring was conducted along a powerline in the vicinity of PBF/CITRC that has been included in various test scenarios. In particular, a large prehistoric campsite designated as BEA-08-29-02 was re-visited to determine if any new impacts were apparent. INL CRM Office staff confirmed that ground disturbance associated with this work continues to be restricted to the existing road corridor and in narrow zones surrounding existing power poles (Figure 6). This is consistent with recommendations made by INL CRM Office staff to protect sensitive resources like BEA-08-29-02, which does not appear to have been impacted by the work.

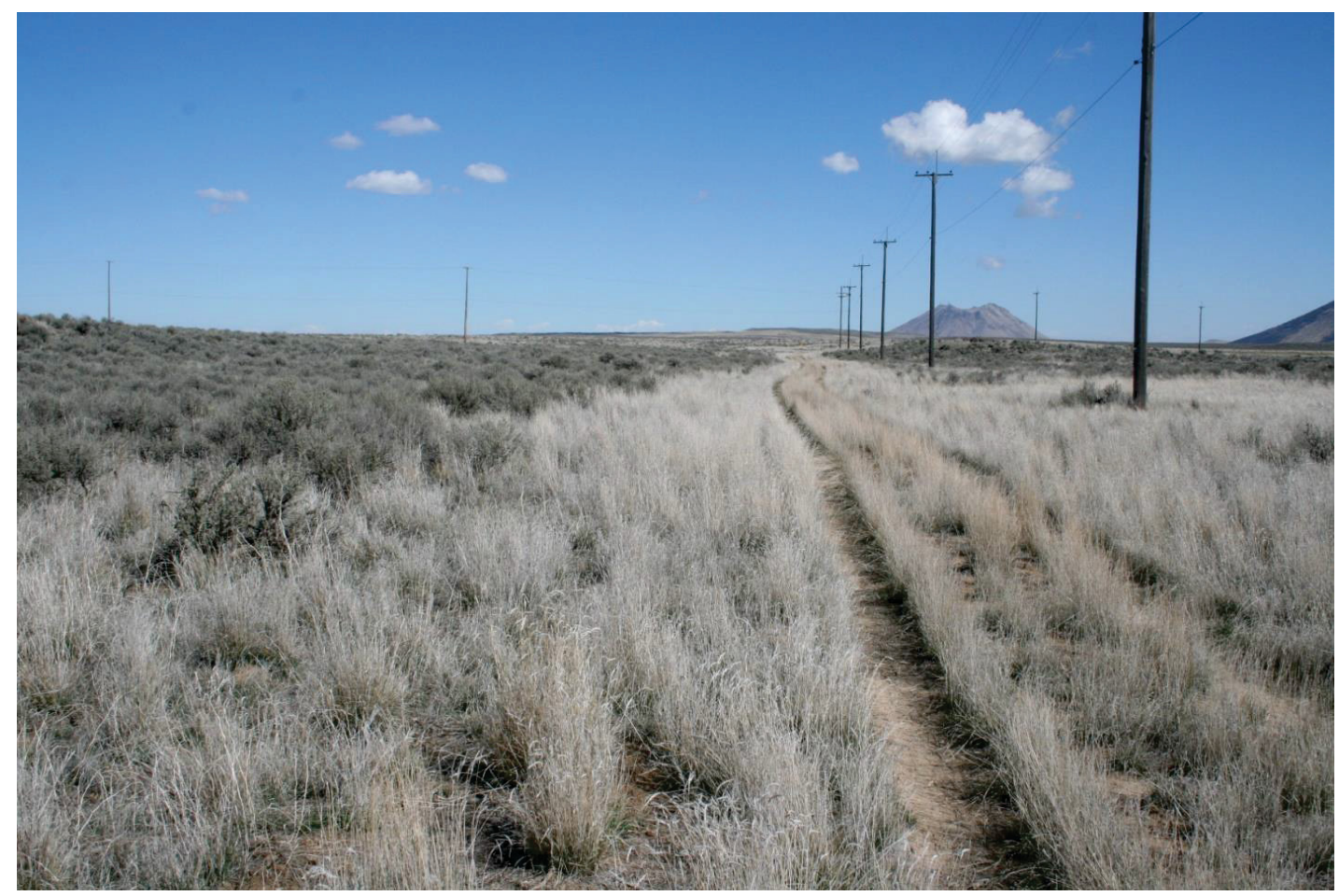

Figure 6. Powerline and Road associated with National and Homeland Security Project near Site BEA08-29-02.

\subsubsection{National Security Test Range}

Large scale explosive testing at INL's National Security Test Range has the potential to disrupt prehistoric rock features at an important prehistoric campsite (10-JF-88/Hellofasite). Each year, this resource is revisited to determine if any impacts have occurred and if any protective measures are necessary. To date, no impacts related to the explosive testing have been identified. This was true in 2013; no impacts associated with explosive testing were observed. Impacts associated with looting and unauthorized artifact removal observed at this site in 2011 were still apparent and are under continuing investigation by federal law enforcement agents. Fortunately, no new impacts were observed in 2013. 


\subsubsection{Power Burst Facility/Critical Infrastructure Test Range Complex}

Company environmental procedures require project managers to contact the INL CRM Office in advance of ground disturbance within the fenced boundary of PBF/CITRC. This is due to the occurrence of human remains in original as well as secondary (i.e. disturbed) contexts at two separate locations within the facility (10-BT-2046 and 10-BT-1991). In 2013, a variety of ongoing projects associated with the INL National and Homeland Security program continued at PBF/CITRC, including removal of old waterline pipes from a soil berm (Figure 7) and grading and leveling of gravel pads near 10-BT-1991 to support a new Water Security Test Bed project, installation of temporary test equipment to support a new wireless project, and excavation for new utility connections near 10-BT-2046 (Figure 8) to support the installation of new office trailers. On six occasions in 2013, ground disturbance of this nature was monitored for human remains or other sensitive cultural materials. No sensitive materials were observed at any time. As part of monitoring for the new Water Security Test Bed project, one previously recorded prehistoric site, 10-BT-1148, was also revisited in 2013 to ensure that berm and pipe removal did not cause any new impacts.

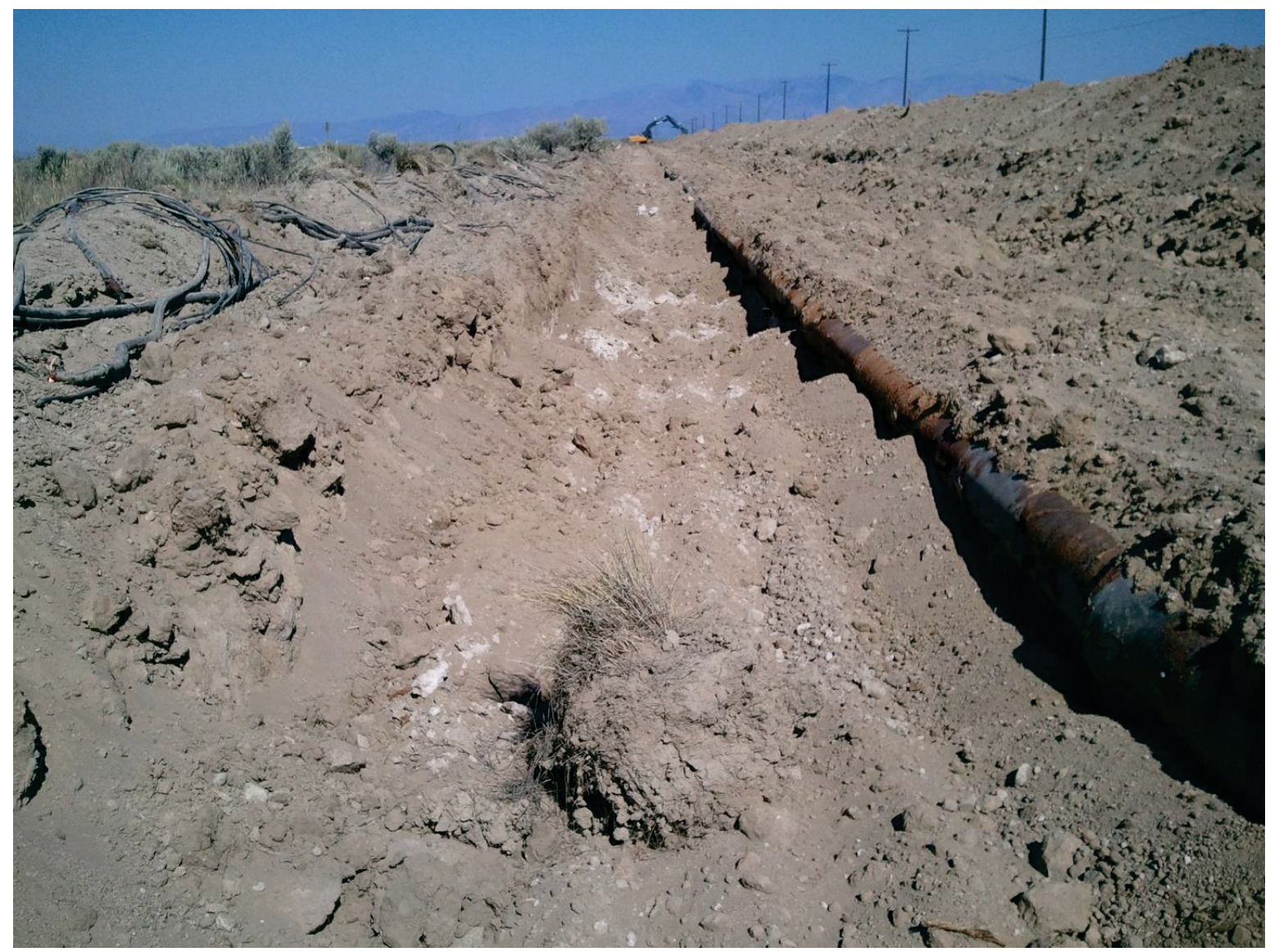

Figure 7. Removal of gravel/soil berm and old water line pipe at PBF/CITRC monitored by INL CRM staff in 2013. 


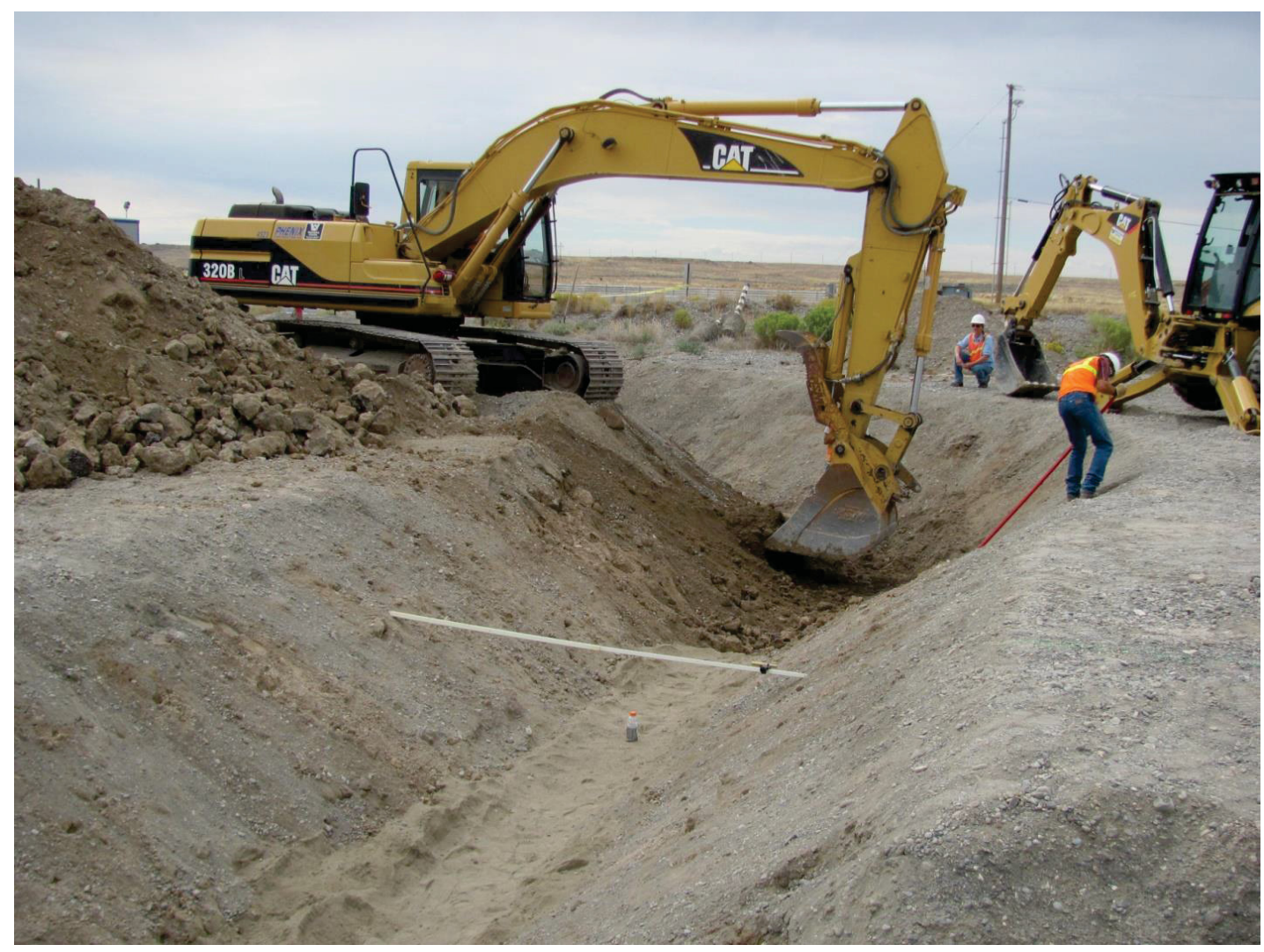

Figure 8. INL CRM Office staff monitoring of ground disturbance at PBF/CITRC.

\section{RECOMMENDATIONS}

Monitoring is an effective method of documenting impacts to INL cultural resources and is a necessary first step in impact identification and prevention. Several broad recommendations resulted from 2013 surveillance. First, at a minimum, the condition of the following resources of high sensitivity should be reassessed in 2014:

- WERF Remains (10-BT-2046)

- Prickly Cave (10-BT-2037)

- Middle Butte Cave (10-BM-34)

- Aviators Cave (10-BT-1582)

- Igloo Cave

- $\quad$ East Boundary Cave (10-BV-82)

- Powell Stage Station (10-BT-2194)

- Goodale's Cutoff

- Hellofasite (10-JF-88)

- Experimental Breeder Reactor I National Historic Landmark

- World War II Proofing Area (CF-633) and post war structures (i.e., roads, targets, detonation areas) 
Cultural resource monitoring in 2014 should also be focused on several broad classes of other INL cultural resources and projects, as funding allows. Minimally, this might include:

- Any soil disturbance at the PBF/CITRC area to monitor for additional occurrences of sensitive human remains, even in disturbed contexts

- Areas impacted by wildfire suppression activities

- Archaeological sites located in high traffic areas such as the INL Boundary and Grazing Boundary or where unauthorized visitation is likely

- Historic homesteads, including those identified during ongoing archival research

- Buttes, craters, and caves (surface only unless there is evidence of unauthorized activity)

- Livestock-related impacts to historic trails

- Powerlines that cross INL lands

To address ongoing Type 2 and Type 3 impacts related to unauthorized visitation, INL CRM staff will continue to work closely with DOE-ID, HeTO tribal representatives, when appropriate, and federal experts in Archaeological Resource Protection Act (ARPA) enforcement, INL security and landlord organizations, and individual project personnel, as appropriate, to implement more effective protections. For Type 2 impacts related to the CFA structures, INL CRM staff will continue to facilitate legallymandated consultation between DOE-ID, BEA Facilities managers, DOE-HQ Chief Historian/Federal Preservation Officer, the Idaho SHPO, and the ACHP and advise DOE-ID and BEA Facilities managers on appropriate measures to mitigate the adverse impacts that planned demolition will cause and preservation treatments for the World War II structures that will remain.

\section{REFERENCES CITED}

36 CFR 60.4 "Criteria for Evaluation”, Code of Federal Regulations, Office of the Federal Register.

Braun, J. B., 2006, “Experimental Breeder Reactor I Historic Structure Report, INL/EXT-06-1 1909. Idaho Falls, ID.

DOE-ID, 1994, Memorandum of Agreement, "Middle Butte Cave," between the U. S. Department of Energy, Idaho Operations Office and the Shoshone-Bannock Tribes, January 26, 1994.

DOE-ID, 1996, “Comprehensive Facility and Land Use Plan,, DOE/ID-10514. Idaho Falls, ID.

DOE-ID, 2013a, "Idaho National Laboratory Cultural Resource Management Plan", DOE/ID-10997, Rev 5, February 2013. Idaho Falls, ID.

DOE-ID, 2013b, “Idaho National Laboratory Site Environmental Report Calendar Year 2012”, DOE/ID12082(12), September 2013.

DOE-ID, 2013c, "Environmental Assessment for the Resumption of Transient Testing of Nuclear Fuels and Material", DOE/EA-1954, October 2013.

Irving, J. S., editor, 1993, "Environmental Resource Document for the Idaho National Engineering Laboratory," EGG-WMO-10279. Idaho Falls, ID.

LWP-8000, BEA (INL), Laboratory-Wide Procedure, Environmental Instructions for Facilities, Processes, Materials and Equipment.

LWP-8500, BEA (INL), Laboratory -Wide Procedure, INL Cave Protection and Access. 
LWP-14002, BEA (INL), Laboratory-Wide Procedure, Stop Work Actions.

MCP-553, CWI (ICP), Management Control Procedure, Step Back and Stop Work Authority.

MCP-3480, CWI (ICP), Management Control Procedure, Environmental Instructions for Facilities, Processes, Materials and Equipment.

Pace, B. R. and J. B. Williams, 2013, "Cultural Resource Investigations for the Resumption of Transient Testing of Nuclear Fuels and Material at the Idaho National Laboratory," INL/EXT-13-29097, June 2013. 
Appendix A

\section{Monitoring Forms}




\section{Appendix A Monitoring Forms}

Appendix A contains electronic versions of FY 2012 monitoring forms originally completed in the field. The forms are organized according to the following categories presented in the preceding report:

- Native American Human Remains

- Caves

- Prehistoric Archaeological Resources

- Historic Archaeological Resources

- Historic Trails

- Modern Resources

- Projects 
A: Native American Human Remains 
Idaho National Laboratory Cultural Resource Management Office Field Monitoring Form

Monitor Number: 2013-HR-1

Monitor Name(s): $\quad$ Hollie Gilbert, Julie B. Williams, Christina Olson, Carolyn Boyer-Smith

Monitor Date: $\quad$ September 18, 2013

Project:

CRMO monitoring

Site Name/Number: $\quad$ Prickly Cave (10-BT-2037)

Reason for monitoring: $\quad$ Required annual monitoring with Shoshone-Bannock tribal representatives.

Findings:

\begin{tabular}{|l|l|}
\hline Type 1 & $\mathrm{x}$ \\
\hline
\end{tabular}

\begin{tabular}{|l|l|}
\hline Type 2 & \\
\hline
\end{tabular}

Type 3

Type 4

Impact Agent(s): $\quad$ None - no site disturbance noted

Significance of Impact:

Did disturbance or impact extend into undisturbed areas?

Yes

No

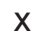

If yes, describe:

Work Halted?

If yes, describe:

Yes

No $x$

Notifications:

Contact Method: N/A

Cultural Materials observed? Yes $x$ No $\square$

If yes, describe: Previously recorded surface artifacts are present across the site. However no materials from inside the cave appear to have been disturbed.

Cultural Materials collected?

Yes

No $x$

If yes, describe: N/A

General Comments: Site appears to be stable. Cave was not entered this year due to DOE moratorium on cave entry. Bat detection equipment was present at site.

Recommendations: $\quad$ Continue to monitor annually 
Idaho National Laboratory Cultural Resource Management Office Field Monitoring Form

Monitor Number: $\quad$ 2013-HR-2

Monitor Name(s): $\quad$ Hollie Gilbert, Julie B. Williams, Christina Olson, Carolyn Boyer-Smith

Monitor Date: $\quad$ September 18, 2013

Project:

CRMO monitoring

Site Name/Number: $\quad$ WERF Burial (10-BT-2046)

Reason for monitoring: $\quad$ Required annual monitoring with Shoshone-Bannock tribal representatives.

Findings:

\begin{tabular}{|l|l|}
\hline Type 1 & $\mathrm{x}$ \\
\hline
\end{tabular}

\begin{tabular}{|l|l|}
\hline Type 2 & \\
\hline
\end{tabular}

Type 3

Type 4

Impact Agent(s): $\quad$ None - no site disturbance noted

Significance of Impact: N/A

Did disturbance or impact extend into undisturbed areas?

Yes

No

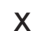

If yes, describe:

Work Halted? Yes

No $x$

If yes, describe:

N/A Yes $\square$ No $\mathrm{x}$

Notifications:

$\mathrm{N} / \mathrm{A}$

Contact Method:

E-mail

Phone

Official correspondence, CCN\#:

Cultural Materials observed? Yes $\square$ No $\quad x$

If yes, describe: Earthen cap over human remains intact and no cultural materials were observed

Cultural Materials collected?

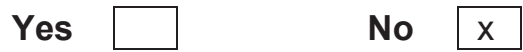

If yes, describe: N/A

General Comments: Fence is starting to sag and rodent burrows from last appear to have no current rodent activity.

Recommendations: $\quad$ Continue to monitor annually 


\section{A: Caves}


Monitor Number: 2013-Cave-1

Monitor Name(s): $\quad$ Brenda Pace, Jericho Whiting, Bryan Bybee

Monitor Date: $\quad$ February 5, 2013

Project: $\quad$ Bat research - Winter Hibernation Counts

Site Name/Number: $\quad$ North Tower Cave - Earl/10-BM-96

Reason for monitoring: Observe and assist with project to avoid impacts to sensitive cultural resources, facilitate tribal involvement, and establish baseline cultural resource sensitivity.

Findings:

\begin{tabular}{|l|l|}
\hline Type 1 & $\mathrm{x}$ \\
\hline
\end{tabular}

Type 2

Type 3

Type 4

Impact Agent(s): $\quad$ No impacts from bat research. Old, shallow excavations may indicate past looting and unauthorized visitation.

Significance of Impact: $\quad$ Bat researchers were aware of cultural resource sensitivities and avoided all impacts. No footprints or recent excavations were apparent to indicate ongoing looting or unauthorized visitation.

Did disturbance or impact extend into undisturbed areas?

Yes $x$

No

If yes, describe: $\quad$ Old shallow excavations were found throughout the interior of the cave. No recent disturbances were observed.

Work Halted?

If yes, describe:

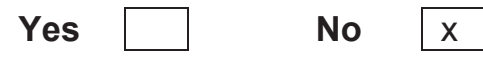

Notifications: $\quad$ None required under Type I finding.

Primary Contact(s):

Date(s) Contacted:

Contact Method(s): | E-mail $\square$ Phone $\square$ Official correspondence, CCN\#:

Cultural Materials observed? Yes $x$ No $\square$

If yes, describe: $\quad$ Milled wood, sage torches, large mammal bones on surface. Older, informal, shallow excavations are present and one includes obvious charcoal layer.

Cultural Materials Collected? Yes $\square$ No $\quad \mathrm{x}$

If yes, describe:

General Comments: Cave presents easy walk-in access. Single long cavern $(\sim 110 \mathrm{~m})$ with two short arms (10-20m) near the end. Dry, dusty soil with some rocky stretches.

Archaeological potential is high. Three Townsends Big Eared bats 40-70m from entrance. Pigeons are roosting at entrance ( 25). Locational information withheld for resource protection.

Recommendations: $\quad$ Repeat visit, as allowed, for further evaluation of archaeological potential.

Attach additional documentation, as warranted (photos, profiles, etc.)

Yes

No $x$ If yes, describe: 
Monitor Number: 2013-Cave-2

Monitor Name(s): $\quad$ Brenda Pace, Jericho Whiting, Bryan Bybee

Monitor Date:

February 5, 2013

Project:

Site Name/Number:

Bat research - Winter Hibernation Counts

Reason for monitoring:

East Boundary Cave/10-BV-82

Observe and assist with project to avoid impacts to sensitive cultural

resources, facilitate tribal involvement, and establish baseline cultural resource sensitivity.

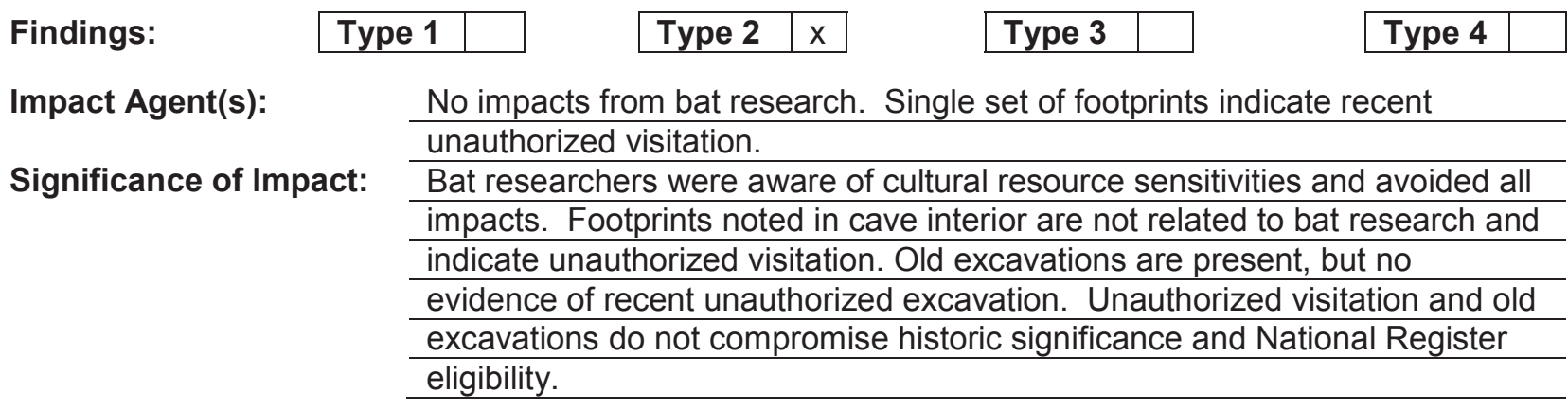

$\begin{array}{lll}\text { Did disturbance or impact extend into undisturbed areas? } & \text { Yes } & x\end{array}$

If yes, describe: Recent footprints are continuous and extend entire length of south arm, but sporadic down north arm.

\begin{tabular}{lllll} 
Work Halted? & Yes & & No $\quad \mathrm{x}$ \\
If yes, describe: & N/A & & \\
\hline
\end{tabular}

Notifications: $\quad$ None - initial visit to this cave establishes baseline. If unauthorized visitation is documented a second time, appropriate steps, including notifications, will be taken.

Primary Contact(s):

Date(s) Contacted:

Contact Method(s): | E-mail $\quad \square$ Phone $\quad \square$ Official correspondence, CCN\#:

Cultural Materials observed? Yes $x$ No $\square$

If yes, describe: Entrance area included one obsidian flake, milled wood fragments, sage torches, and bone fragments. Sage torches and large mammal bones also found throughout and

significant packrat activity. Entire cave has evidence of significant historic activity probably related to moonshining. South arm contains old stove, pipe, milled wood. Alcoves high on the wall of this arm may contain additional artifacts. North arm may have been closed off at one point and vertical floor-to-ceiling timbers and partial walls remain in place. Historic artifacts are densely concentrated in the north arm as well, including: metal strainer, wire, canvas, paint cans, sand bags, wooden boxes (Karo), sheet metal, barrel staves, rubber pipe, metal pipe, glass jars, enamel pots, glass jugs, rusty cans, blue denim coveralls, cut bones, and a large metal stock tank. Time did not allow for a detailed inventory of artifacts.
Cultural Materials Collected?
Yes
No $x$

If yes, describe:

General Comments: Cave entrance is a short drop $(2.5 \mathrm{~m})$. Two main arms extend north and south from entrance. North arm is $\sim 190 \mathrm{~m}$ long with some curves and periodic break down; south arm is $\sim 60 \mathrm{~m}$ long. High alcoves in each arm were not explored. Soils dry and dusty with packrat evidence, coyote scat, live insects (at entrance), 
Idaho National Laboratory Cultural Resource Management Office Field Monitoring Form

antelope and rabbit carcasses. Shallow runoff channels extend down each arm ( $20 \mathrm{~cm}$ wide, $10 \mathrm{~cm}$ deep). Air movement is notable. South arm had 8 bats $10-$ $50 \mathrm{~m}$ from entrance (Townsends Big Eared); North arm had 9 Townsends 70-. $100 \mathrm{~m}$ from entrance and 1 at $120 \mathrm{~m}$, plus 1 small footed myotis at $60 \mathrm{~m}$ and another at $180 \mathrm{~m}$. Archaeological potential is high for early 1900s moonshining activity and also for prehistoric archaeology throughout the cave. Locational information withheld for resource protection.

Recommendations: $\quad$ Repeat visit, as allowed, for further evaluation of archaeological potential. Schedule additional monitoring of exterior to assess level of unauthorized visitation and any associated impacts. Consider additional cave entries if unauthorized visitation is indicated.

Attach additional documentation, as warranted (photos, profiles, etc.)

Yes

No $x$ If yes, describe: 
Monitor Number: 2013-Cave-3

Monitor Name(s): Brenda Pace, Jericho Whiting, Bryan Bybee

Monitor Date:

February 5, 2013

Project:

Site Name/Number:

Bat research - Winter Hibernation Counts

Reason for monitoring: Jeep Trail Cave

Observe and assist with project to avoid impacts to sensitive cultural resources, facilitate tribal involvement, and establish baseline cultural resource sensitivity.

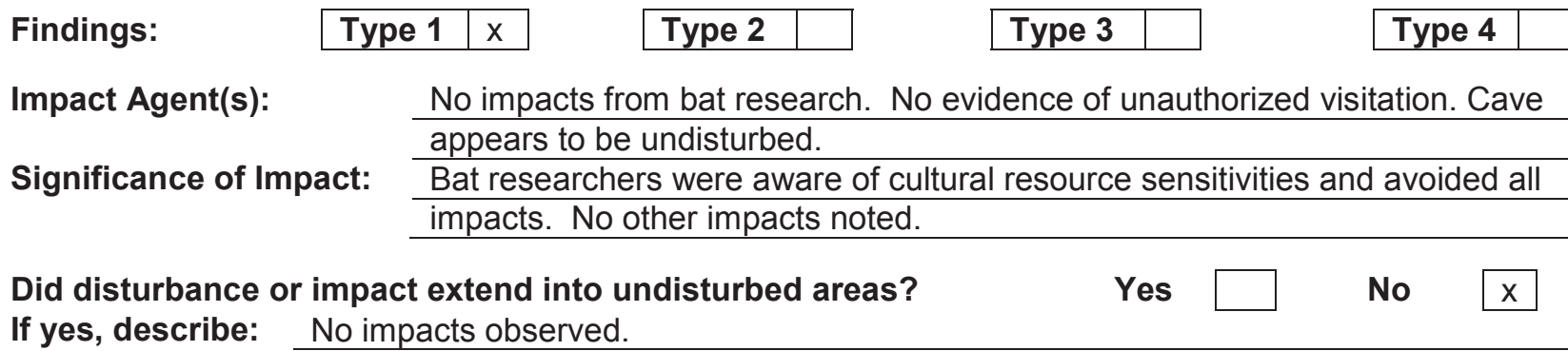

Work Halted? Yes $\square$ No $x$

If yes, describe:

\begin{tabular}{llll} 
& Yes \\
$\mathrm{N} / \mathrm{A}$ & & No $\mathrm{X}$ \\
\hline
\end{tabular}

Notifications: $\quad$ None required under Type I finding.

Primary Contact(s):

Date(s) Contacted:

Contact Method(s): | E-mail $\square$ Phone $\square$ Official correspondence, CCN\#:

\section{Cultural Materials observed? \\ Yes $\mathrm{x}$ \\ No}

If yes, describe: $\quad$ Possible sage torches observed in breakdown at entrance.

Cultural Materials Collected? Yes $\square$ No $\quad \mathrm{x}$

If yes, describe:

General Comments: Cave presents easy crawl-in access. Tube is very shallow with two arms that extend only $10-12$ m laterally. Ice crystals, icicles, and ice stalactites cover the entrance. Heavy odor of packrat indicates that organic materials (sage sticks, prickly pear pads, etc) at the entrance may be natural rather than cultural. Many rabbit tracks in the snow go into the cave. No bats observed - temperatures were too low and cave interior too small. Cave is very small, but may contain archaeological materials. Ice formations were beautiful, but prevented full assessment of cave interior. Locational information withheld for resource protection.

Recommendations: $\quad$ Repeat visit, as allowed, for further evaluation of archaeological potential.

Attach additional documentation, as warranted (photos, profiles, etc.) $\quad$ Yes $\square$ No \begin{tabular}{l|l|l|}
\hline \\
\end{tabular} If yes, describe: 
Idaho National Laboratory Cultural Resource Management Office

Field Monitoring Form

Monitor Number: 2013-Cave-4

Monitor Name(s): Brenda Pace, Jericho Whiting, Bryan Bybee

Monitor Date:

February 5, 2013

Project:

Site Name/Number:

Bat research - Winter Hibernation Counts

Reason for monitoring:

Lek Cave

Observe and assist with project to avoid impacts to sensitive cultural resources, facilitate tribal involvement, and establish baseline cultural resource sensitivity.

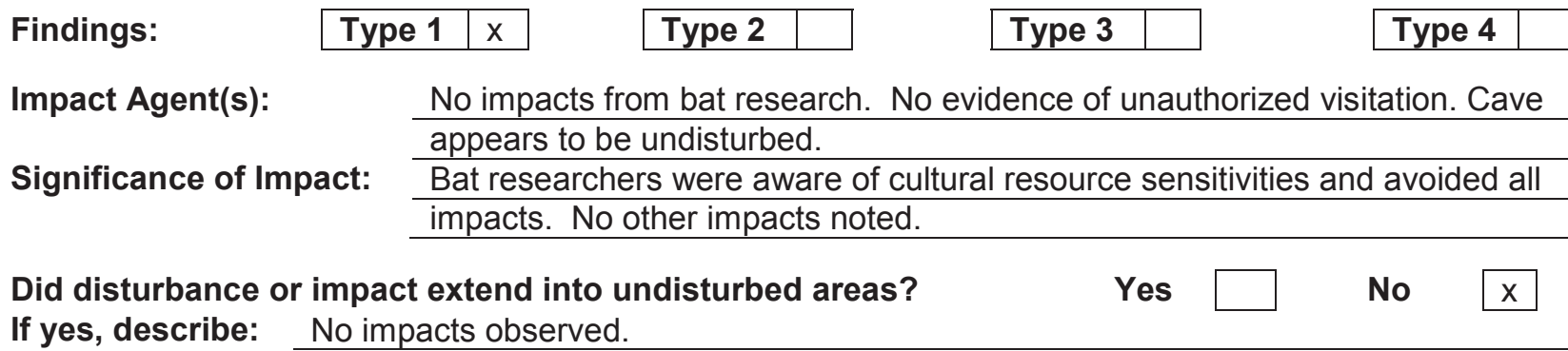

Work Halted?

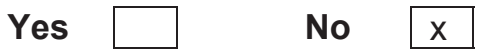

If yes, describe:

\begin{tabular}{llll} 
& Yes \\
$\mathrm{N} / \mathrm{A}$ & & $\mathrm{N}$ \\
\hline
\end{tabular}

Notifications: $\quad$ None required under Type I finding.

Primary Contact(s):

Date(s) Contacted:

Contact Method(s): | E-mail $\square$ Phone $\square$ Official correspondence, CCN\#:

Cultural Materials observed? Yes $\square$ No $\mathrm{X}$

If yes, describe: No artifacts observed.

$\begin{array}{llll}\text { Cultural Materials Collected? No } & \text { Nos } \\ \end{array}$

If yes, describe:

General Comments: Cave presents easy walk-in access via a large, deep crater. Smaller secondary crater forms a skylight. Ceilings are extremely high, cathedral-like in places. Quick exploration revealed openings in floor, but no obvious passages. Rock surfaces were covered with icy sheen and temperatures were very cold. Green lichen present on may rock surfaces. No bats present, but many rabbit tracks led into cave. Rock surfaces were smooth and suitable for rock art. Rocky floor has less potential for archaeological deposits, but many underground openings were not fully explored. Locational information withheld for resource protection.

Recommendations: $\quad$ Repeat visit, as allowed, for further evaluation of archaeological potential.

Attach additional documentation, as warranted (photos, profiles, etc.) $\quad$ Yes $\square$ No $\quad x$ If yes, describe: 
Monitor Number: 2013-Cave-5

Monitor Name(s): $\quad$ Brenda Pace, Jericho Whiting, Romelia Martinez

Monitor Date: $\quad$ February 8, 2013

Project: $\quad$ Bat research - Winter Hibernation Counts

Site Name/Number: Link Sausage Cave

Reason for monitoring: Observe and assist with project to avoid impacts to sensitive cultural resources, facilitate tribal involvement, and establish baseline cultural resource sensitivity.

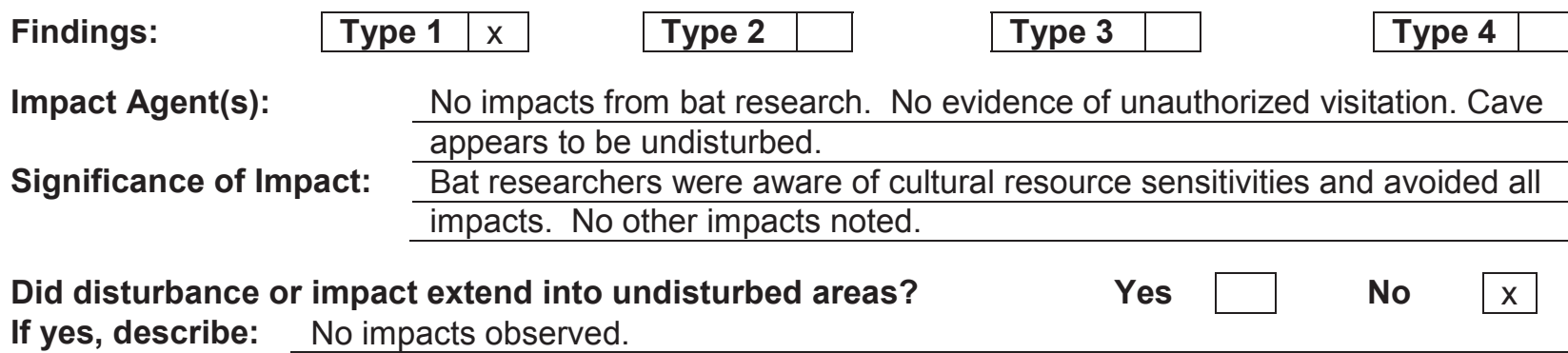

$\begin{array}{lllll}\begin{array}{l}\text { Work Halted? } \\ \text { If yes, describe: }\end{array} & \text { N/A } & \text { Nos } & \\ \end{array}$

Notifications: $\quad$ None required under Type I finding.

Primary Contact(s):

Date(s) Contacted:

Contact Method(s): | E-mail $\quad \square$ Phone $\square$ Official correspondence, CCN\#:

Cultural Materials observed? Yes $\mathrm{x}$ No $\square$

If yes, describe: Sage torch found after first constriction and additional torches and other wooden artifacts are probably included among debris that has been collected by pack rats.

The packrat middens are also substantial and appear old - may have paleoecological potential. Lava formations are unique.

Cultural Materials Collected? Yes $\square$ No $\mathrm{X}$

If yes, describe:

General Comments: Cave presents crawl-in access via a wide but shallow opening. Entrance room is cold with low ceiling. Single tube extends from entrance to a very narrow constriction. Tube continues past this narrow spot to a large room. True to its name, the tube includes two additional tight constrictions with larger rooms between. Overall length is approximately $117 \mathrm{~m}$. Five Townsends Big Eared bats were found in the large room after the first constriction. No bats were observed further back in the cave. Soils are dry and dusty throughout and large packrat middens are present. Evidence of rabbits and a bobcat skull are located in the room that contained bats. Far end of cave has air movement, a large dirt fan, and a small runoff channel $(\sim 10 \mathrm{~cm}$ wide, $20 \mathrm{~cm}$ deep). Dry soils present potential for archaeological deposits throughout the cave. Room after the second constriction contains significant geological features (ropes, drips, droplets, rivulets). Locational information withheld for resource protection.

Recommendations: $\quad$ Repeat visit, as allowed, for further evaluation of archaeological potential.

Attach additional documentation, as warranted (photos, profiles, etc.) Yes $\square$ No $x$ If yes, describe: 
Monitor Number: 2013-Cave-6

Monitor Name(s): $\quad$ Brenda Pace, Jericho Whiting, Romelia Martinez

Monitor Date:

February 8, 2013

Project:

Site Name/Number:

Bat research - Winter Hibernation Counts

Reason for monitoring:

Travois Cave

Observe and resource sensitivity.

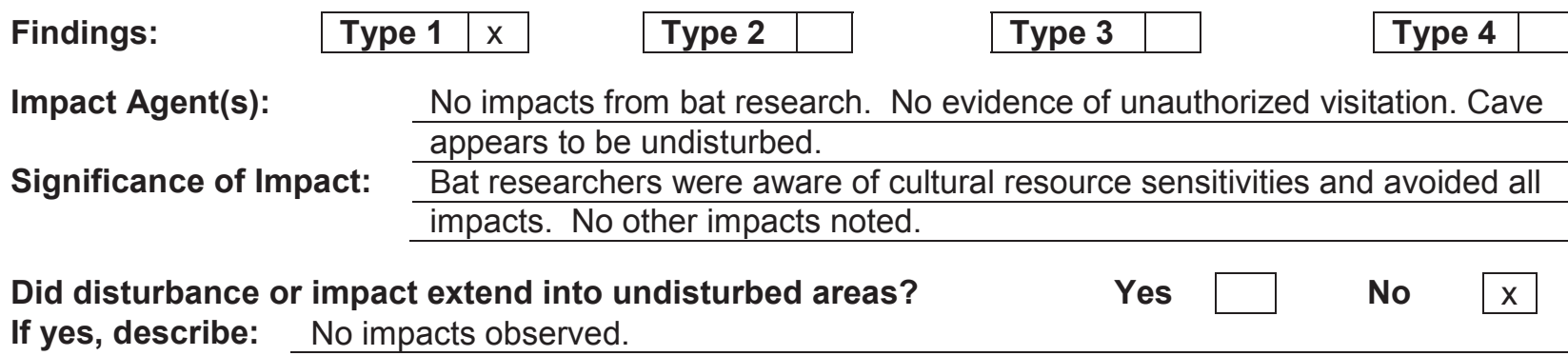

Work Halted?

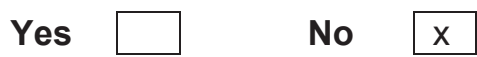

If yes, describe: $\quad \mathrm{N} / \mathrm{A}$

Notifications: $\quad$ None required under Type I finding.

Primary Contact(s):

Date(s) Contacted:

Contact Method(s): | E-mail $\square$ Phone $\square$ Official correspondence, CCN\#:

Cultural Materials observed? Yes $\mathrm{x}$ No $\quad$ ?

If yes, describe: $\quad$ Cave is named for several slender wooden poles found inside ( $6 \mathrm{ft}$ long, 2 in wide).

The poles have semi-squared sides like they may have been square once. One has insect tracks as seen under bark. The poles are wedged in among large roof fall and smaller rocks above a small passage that does not go far laterally. Near the entrance a basalt cobble is wrapped with wire as if used for a weight. Rocky floor of this cave does not contain much soil, but small deeper passages/rooms do have dirt floors where archaeological deposits may be present.
Cultural Materials Collected?
Yes
No $\mathrm{x}$

If yes, describe:

General Comments: Cave presents crawl-in access via a wide but shallow opening. Entrance room is large and full of large and small rock. Much of the rock is jumbled and loose. Air is too cold for bats and none are observed. Small openings to a deeper portion of the cave show dirt floors, but none of these passages go very far. There was not time to fully explore these deeper areas for cultural materials or to look for other artifacts so much of this cave remains unevaluated. Locational information withheld for resource protection.

Recommendations: $\quad$ Repeat visit, as allowed, for further evaluation of archaeological potential.

Attach additional documentation, as warranted (photos, profiles, etc.) $\quad$ Yes $\square$ No \begin{tabular}{|l|l|}
\hline \\
\end{tabular} If yes, describe: 
Monitor Number: 2013-Cave-7

Monitor Name(s): $\quad$ Brenda Pace, Jericho Whiting, Jason Sturm

Monitor Date:

February 11, 2013

Project:

Site Name/Number:

Bat research - Winter Hibernation Counts

Reason for monitoring:

Middle Butte Cave/10-BM-34

Observe and assist with project to avoid impacts to sensitive cultural resources, facilitate tribal involvement, and monitor cultural resources while minimizing cave entries to protect bats.

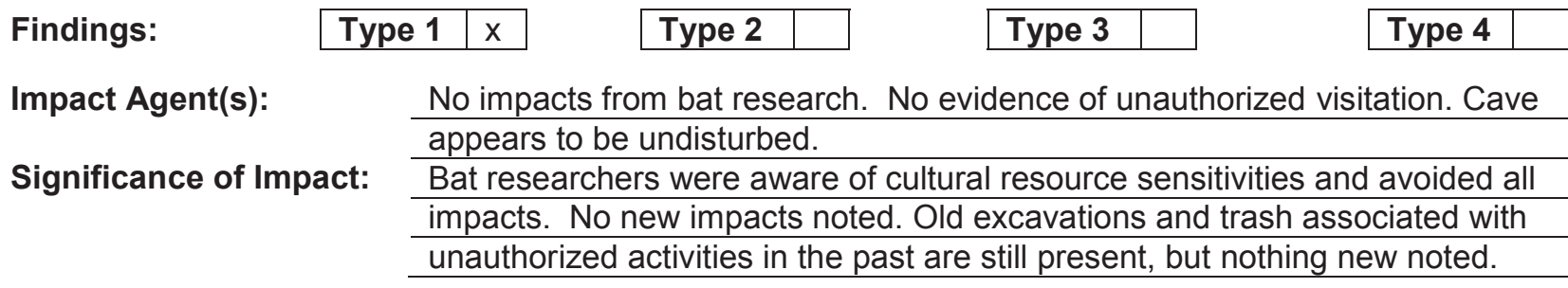

Did disturbance or impact extend into undisturbed areas?

Yes

No

If yes, describe: No impacts observed.

Work Halted?

Yes

If yes, describe: N/A

Notifications: $\quad$ None required under Type I finding.

Primary Contact(s):

Date(s) Contacted:

Contact Method(s): | E-mail $\square$ Phone $\square$ Official correspondence, CCN\#:

Cultural Materials observed? Yes $x$ No $\square$

If yes, describe: $\quad$ Middle Butte Cave is well-known for its cultural and archaeological significance. No new artifacts or rock art panels were observed and known materials exhibited no change. Notable cultural features are prehistoric rock art, historic and modern graffiti, fire rings, limited number of surface artifacts (large mammal bones, wood, occasional obsidian flakes).

Cultural Materials Collected?

Yes

No

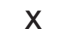

If yes, describe:

General Comments: Middle Butte Cave includes one long ( $615 \mathrm{~m})$ north arm and two shorter south arms ( $60 \mathrm{~m})$. The walk-in entrance to the north arm is broad and cavernous and the tube provides easy upright access with limited crawling required. Entrances to the southern arms are tight and require crawling. Snow was blocking one of the south arms during this visit, so only the SE arm was entered. Two owls fly from the crater as we approach. Large north arm has 400 hibernating bats, most are Townsends big eared, but also a few small footed myotis. Old dig areas, footprints, trash items, and bat carcasses are still present, but no new impacts. SE arm has uniform dirt floor like main north arm and one old excavation near the wall. Sage torches and other wood items are present. Archaeological potential is very high. Ten Townsends big eared bats counted. Locational information withheld for resource protection.

Recommendations: Continue routine monitoring.

Attach additional documentation, as warranted (photos, profiles, etc.) Yes \begin{tabular}{|l|l|l|} 
& \multirow{2}{*}{ No } & \\
& & $\mathrm{x}$ \\
\hline
\end{tabular} If yes, describe: 
Monitor Number: 2013-Cave-8

Monitor Name(s): Brenda Pace, Jericho Whiting, Quinn Shurtliff

Monitor Date:

February 11, 2013

Project:

Bat research - Winter Hibernation Counts

Site Name/Number: College Cave/10-BM-52

Reason for monitoring:

Observe and assist with project to avoid impacts to sensitive cultural resources, facilitate tribal involvement, and establish baseline cultural resource sensitivity.

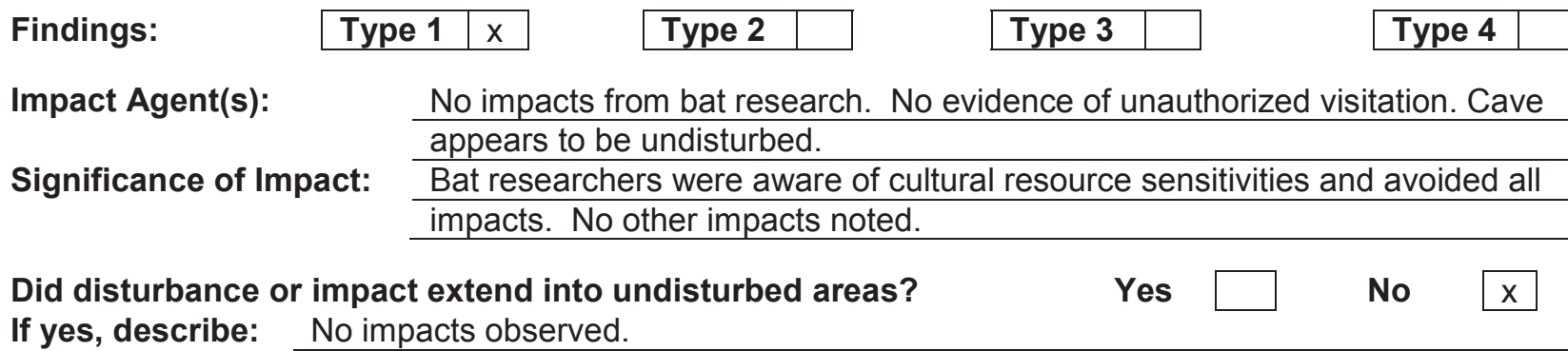

Work Halted?

N/A Nes $\square$ No $x$

If yes, describe:

None required under Type I finding.

Notifications:

Date(s) Contacted:

Contact Method(s): | E-mail $\square$ Phone $\square$ Official correspondence, CCN\#:

Cultural Materials observed? Yes $\mathrm{x}$ No $\square$

If yes, describe: College Cave was excavated by paleontologists from Idaho State University in the in the 1980s, when significant faunal deposits were discovered. Prehistoric rock art is also reported on the original site form and a paleontological publication indicates that obsidian "chips" were encountered in the excavations. Pits, back dirt piles, stakes various metal items, and an old wooden ladder remain from the excavations. Excavations show at least $2+m$ of soil deposits and clear layer of Mazama ash.
Cultural Materials Collected?
Yes
No
$\mathrm{x}$

If yes, describe:

General Comments: Entrance to College Cave is drop-in and requires a ladder. Below ground, the cave is one large room. Old research excavations are still open and Mazama ash is notable in longest trench. Wood and metal debris are present. Old ladder was badly deteriorated and was removed from opening to prevent any future use. Archaeological and paleontological research potential remains high. Three

Townsends big eared bats observed. Temperature change from cold at surface to constant cool inside is notable. Locational information withheld for resource protection.

Recommendations: $\quad$ Repeat visit, as allowed, for further evaluation of research potential. Complete archive search for reports and info on earlier excavations. Visit and assess collections at Idaho Museum of Natural History.

Attach additional documentation, as warranted (photos, profiles, etc.)

Yes No $x$ If yes, describe: 
Monitor Number: 2013-Cave-9

Monitor Name(s): $\quad$ Brenda Pace, Jericho Whiting, Christina Olson

Monitor Date: $\quad$ February 14, 2013

Project: $\quad$ Bat research - Winter Hibernation Counts

Site Name/Number: $\quad$ Moonshiners Cave/10-BM-48

Reason for monitoring: Observe and assist with project to avoid impacts to sensitive cultural resources, facilitate tribal involvement, and establish baseline cultural resource sensitivity.

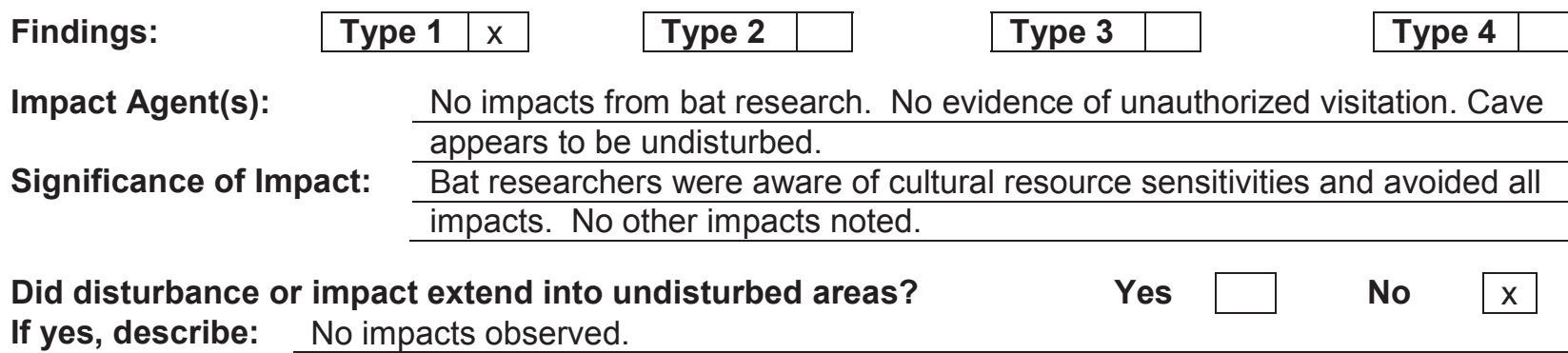

\begin{tabular}{llll|l|l} 
Work Halted? & Yes \\
If yes, describe: & N/A & No $\quad x$ \\
\hline
\end{tabular}

Notifications: $\quad$ None required under Type I finding.

Primary Contact(s):

Date(s) Contacted:

Contact Method(s): | E-mail $\square$ Phone $\square$ Official correspondence, CCN\#:

Cultural Materials observed? Yes $\mathrm{x}$ No $\square$

If yes, describe: Moonshiners Cave is well known for historic archaeological evidence of moonshining activity. Paleontological excavations were conducted by Idaho State University in the 1980s and significant faunal remains demonstrated the importance of the cave as a carnivore trap. Historic artifacts are still present inside the cave including milled wood, rusty cans, barrel staves, wooden box/crate pieces, sheet metal, nails, large mammal bones, old springs that may be a bed or car seat, and stove pieces. A stove or still made of tabular rock and iron stove pipe still stands near the mouth of the longest arm of the cave. A slender pole of wood is jammed into the ceiling above the stove/still. Locational information withheld for resource protection. Cultural Materials Collected? Yes $\square$ No $\mathrm{X}$
If yes, describe:

General Comments: Cave presents drop-in access that requires a ladder. The debris cone at the entrance is covered in ferns that remain green on the edge of the snow cone that has also accumulated there. Entrance room is tall and contains the bulk of historic artifacts and the old stove/still. One long arm extends $\sim 86 \mathrm{~m}$ to the west, requiring a crawl as it angles upward. Toward the end, roots penetrate through the ceiling and water has percolated through and formed drops on ceiling and walls. Soils are deeper closer to the entrance and have clear potential for archaeological deposits associated with historic and prehistoric use. Additional potential for paleontological deposits as well. Two shorter arms extend to the east. Soils are dry and dusty here. Only one Townsends big eared bat observed near entrance. Locational information withheld for resource protection. 
Idaho National Laboratory Cultural Resource Management Office Field Monitoring Form

Recommendations: $\quad$ Repeat visit, as allowed, for further evaluation of archaeological potential.

Attach additional documentation, as warranted (photos, profiles, etc.)

Yes

No $x$ If yes, describe: 
Monitor Number: $\quad$ 2013-Cave-10

Monitor Name(s): $\quad$ Brenda Pace, Jericho Whiting, Bryan Bybee

Monitor Date: $\quad$ February 14, 2013

Project: $\quad$ Bat research - Winter Hibernation Counts

Site Name/Number: Jensens Cave/10-BT-94 and 10-BT-132

Reason for monitoring: Observe and assist with project to avoid impacts to sensitive cultural resources, facilitate tribal involvement, and establish baseline cultural resource sensitivity.

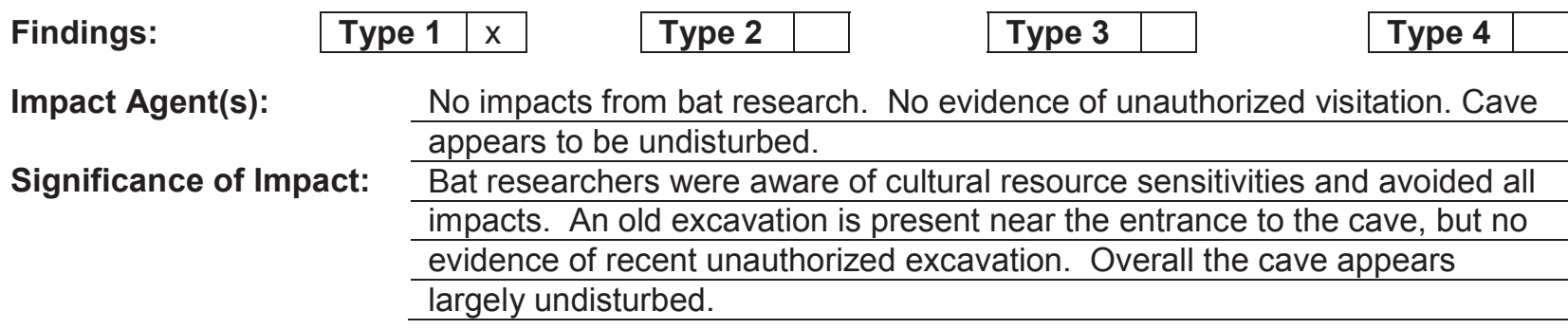

Did disturbance or impact extend into undisturbed areas?

Yes

No

If yes, describe: No new impacts observed.

\begin{tabular}{lllll} 
Work Halted? & Yes \\
If yes, describe: & N/A & No $\quad \mathrm{x}$ \\
\hline
\end{tabular}

Notifications: $\quad$ None required under Type I finding.

Primary Contact(s):

Date(s) Contacted:

Contact Method(s): | E-mail $\square$ Phone $\square$ Official correspondence, CCN\#:

Cultural Materials observed? Yes $\mathrm{x}$ No $\square$

If yes, describe: Jensens cave includes dense scatter of lithic artifacts at the surface. Loose organic material scattered inside the cave includes wood and sage that may be artifacts. Significant packrat activity has occurred and moved cave deposits. Shallow excavation near entrance shows profile of highly disturbed sediment and organic material with no clear stratigraphy of cultural importance.

Cultural Materials Collected? Yes $\square$ No $\quad \mathrm{x}$ If yes, describe:

General Comments: Entrance to Jensens Cave requires a short drop and then crawling throughout the interior because the roof is very low. A ladder is not necessary for access. Interior of cave is cold and icicles are present. Interior of the cave is challenging due to high incidence of organic debris including prickly pear spines. Roof is pocketed with alcoves of many sizes and may present opportunities to cache artifacts or materials. Soils are loose, dry, and dusty and appear very disturbed in the wall of a shallow informal excavation near the entrance. This is probably an animal den, but may represent past looting activities. No bats observed, but webs were common and a black widow spider was observed. Time did not allow full assessment of cultural potential. Locational information withheld for resource protection.

Recommendations: $\quad$ Repeat visit, as allowed, for further evaluation of archaeological potential. Heavy gloves and rubber knee pads will facilitate exploration. 
Idaho National Laboratory Cultural Resource Management Office Field Monitoring Form

Attach additional documentation, as warranted (photos, profiles, etc.)

If yes, describe: 
Monitor Number: $\quad$ 2013-Cave-11

Monitor Name(s): Romelia Martinez, Jericho Whiting, Jack Depperschmidt

Monitor Date:

February 15, 2013

Project:

Site Name/Number:

Bat research - Hibernation Counts

Reason for monitoring:

Aviators Cave/10-BT-1582

Observe and assist with project to avoid impacts to sensitive cultural resources, facilitate tribal involvement, and monitor cultural resources while minimizing cave entries to protect bats.

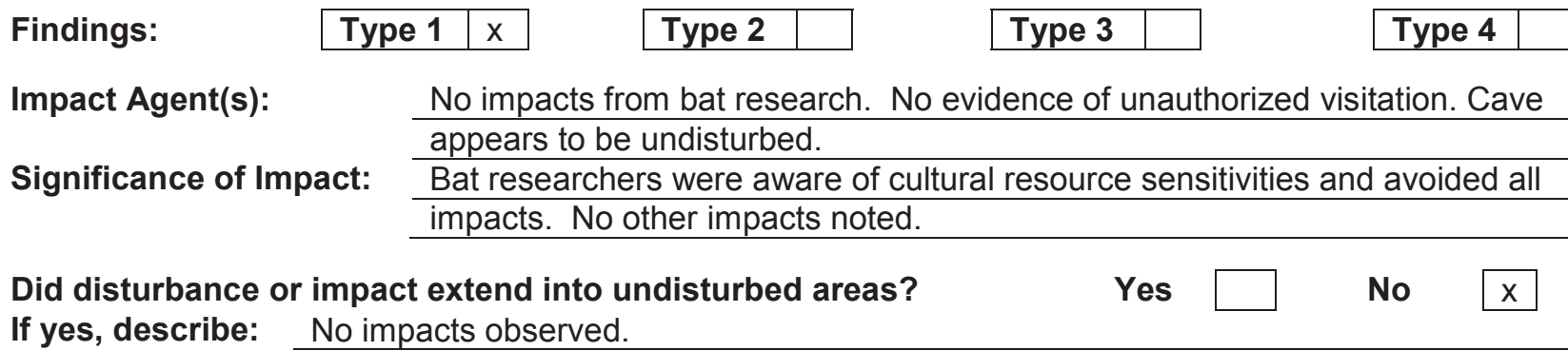

Work Halted?

Yes

No $x$

If yes, describe:

\begin{tabular}{llll} 
& Yes \\
N/A No N & & \\
\hline
\end{tabular}

Notifications: $\quad$ None required under Type I finding.

Primary Contact(s):

Date(s) Contacted:

Contact Method(s): | E-mail $\quad$ Phone $\quad$ Official correspondence, CCN\#:

\section{Cultural Materials observed? Yes $x$ No $\square$}

If yes, describe: $\quad$ Aviators Cave contains significant cultural resources and Shoshone-Bannock tribal values and is listed on the National Register of Historic Places. In order to minimize the number of people entering INL caves to protect vulnerable bats, INL CRM staff did not participate in this monitoring visit in FY 2013. Close communication with Romelia Martinez revealed that no new impacts were observed and all known cultural materials of importance remain undisturbed.

\section{$\begin{array}{llll}\text { Cultural Materials Collected? } & \text { Yes } \\ & & \mathrm{X}\end{array}$} If yes, describe:

General Comments: Romelia Martinez, HeTO representative, participated in the cave entry to count wintering bats. Romelia is familiar with the important artifacts contained within the cave and reported no new impacts or disturbances of sensitive materials.

Recommendations: Continue routine monitoring of surface and interior of cave, as deemed necessary. Locational information withheld for resource protection.

Attach additional documentation, as warranted (photos, profiles, etc.)

Yes

No $x$ If yes, describe: 
Monitor Number: $\quad$ 2013-Cave-12

Monitor Name(s): Brenda Pace, Jericho Whiting, Betsy Holmes

Monitor Date:

February 25, 2013

Project:

Bat research - Winter Hibernation Counts

Site Name/Number: Rattlesnake Cave

Reason for monitoring:

Observe and assist with project to avoid impacts to sensitive cultural resources, facilitate tribal involvement, and establish baseline cultural resource sensitivity.

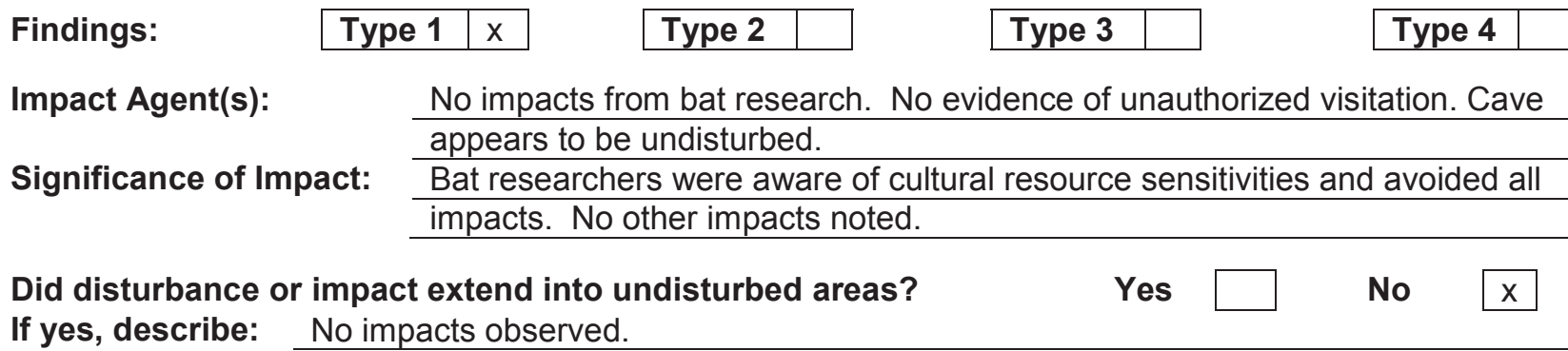

Work Halted? Yes No $x$

If yes, describe:

\begin{tabular}{llll} 
& Yes \\
$\mathrm{N} / \mathrm{A}$ & & $\mathrm{x}$ \\
\hline
\end{tabular}

Notifications: $\quad$ None required under Type I finding.

Primary Contact(s):

Date(s) Contacted:

Contact Method(s): | E-mail $\square$ Phone $\square$ Official correspondence, CCN\#:

\section{Cultural Materials observed? Yes $\mathrm{x}$ No}

If yes, describe: Paleontologists from Idaho State University completed excavations in the east arm of Rattlesnake Cave in 1977. Significant paleontological deposits were documented.

Sage torches, possible arrow shaft, and cut cane pieces were observed on the surface in the western arm during bat counts. Large mammal bones are also common throughout all arms.
Cultural Materials Collected?
Yes
No
$\mathrm{x}$
If yes, describe:

General Comments: The entrance to Rattlesnake cave is massive and via a large collapsed crater.

A Great Horned owl flies from the west chamber to the east as we approach.

One long arm extends to the west $\sim 310 \mathrm{~m}$. Wood and cane artifacts were observed in this arm and soil deposits may contain significant additional archaeological materials and deposits. Further reaches of long arm exhibit unique geological features (flow patterns in floor and ceiling, high ledges, multiple flows, lava drips and rivulets, sparkly mineral inclusions, jasper nodules). Time did not permit a full evaluation of archaeological potential, but it appears to be very high with deep soil deposits and existing surface artifacts. Rattlesnakes will obviously be the limiting factor for any future investigations. Many snake skeletons were observed during the bat count. More than 100 Townsends big eared bats and 24 small footed myotis were observed in the long arm. The shorter, eastern arm of the cave is very open for most of its length, except for a short crawl. Soils are deep here and two old test pits $\sim 2 \mathrm{~m}$ in depth are present. Again, archaeological potential is high. No bats were observed in this shorter arm, which is open to surface air through a large entrance area. 
Idaho National Laboratory Cultural Resource Management Office Field Monitoring Form

Locational information withheld for resource protection.

Recommendations: $\quad$ Repeat visit, as allowed, for further evaluation of archaeological potential.

Attach additional documentation, as warranted (photos, profiles, etc.)

Yes

No $x$

If yes, describe: 
Monitor Number: 2013-Cave-13

Monitor Name(s): Brenda Pace, Jericho Whiting, Bryan Bybee

Monitor Date:

February 25, 2013

Project:

Site Name/Number:

Bat research - Winter Hibernation Counts

Reason for monitoring: Lost Cave

Observe and assist with project to avoid impacts to sensitive cultural resources, facilitate tribal involvement, and establish baseline cultural resource sensitivity.

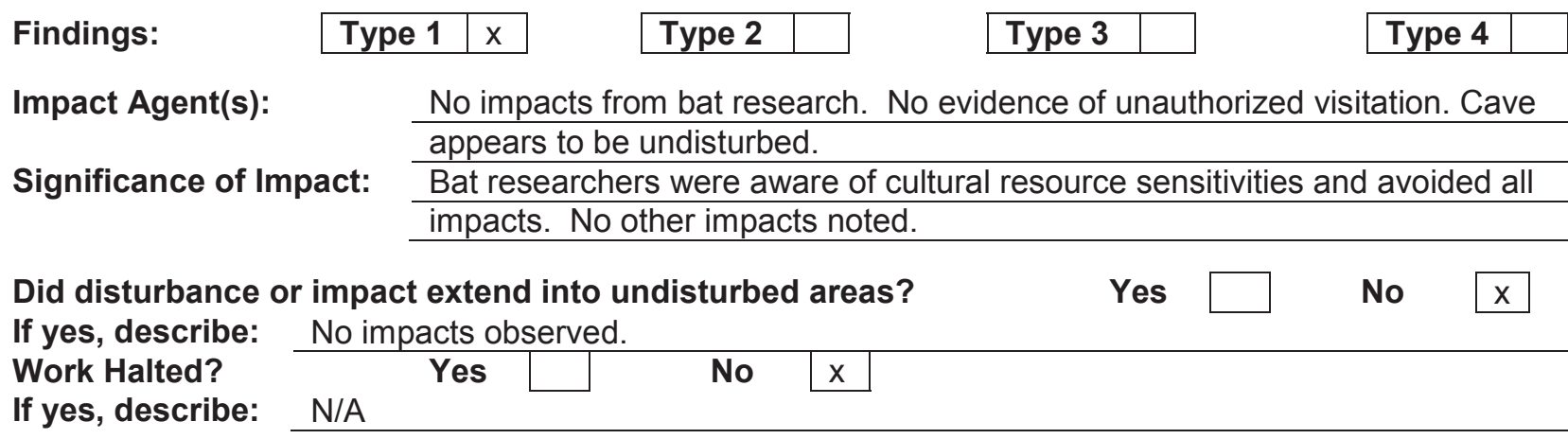

Notifications: $\quad$ None required under Type I finding.

Primary Contact(s):

Date(s) Contacted:

Contact Method(s): | E-mail $\square$ Phone $\square$ Official correspondence, CCN\#:

Cultural Materials observed? Yes $\mathrm{x}$ No

If yes, describe: The cave floor beneath the drop-in entrance of Lost Cave includes a stack of rocks that may have been placed to facilitate entry. Archaeological potential of this cave remains unevaluated due to the limited amount of time available for exploration. Moist soil deposits could contain archaeological materials. Large mammal bone fragments were observed in the cave and this combined with rabbit carcasses also indicate clear potential for paleontological materials.

$\begin{array}{llll}\text { Cultural Materials Collected? } & \text { Yes } \\ \end{array}$ If yes, describe:

General Comments: Warm air blows from the entrance of this cave, creating an ice rind around the drop-in entrance hole. A ladder is needed to enter the cave. The interior of the cave is very warm and humid. Artifact preservation will be affected by this, but perhaps not negatively if conditions have remained constant. Setting is not conducive to bat hibernation and no bats were observed. Very little time was spent exploring the interior of the cave and archaeological potential remains largely unevaluated. Moist soil deposits could yield archaeological materials though, and paleontological potential as a natural faunal trap is very high as indicated by the large mammal bones and occasional rabbit carcasses observed.

Brief exploration revealed two long arms that each extend $\sim 100 \mathrm{~m}$ in opposite directions from the drop-in entrance. Locational information withheld for resource protection.

Recommendations: $\quad$ Repeat visit, as allowed, for further evaluation of archaeological potential.

Attach additional documentation, as warranted (photos, profiles, etc.) $\quad$ Yes $\square$ No \begin{tabular}{ll|l|}
\hline \\
\hline
\end{tabular} If yes, describe: 
Monitor Number: $\quad$ 2013-Cave-14

Monitor Name(s): Brenda Pace, Jericho Whiting, Bryan Bybee

Monitor Date:

February 25, 2013

Project:

Site Name/Number:

Bat research - Winter Hibernation Counts

North Tower Cave - Wakenhut/10-BM-96
Reason for monitoring:
Observe and assist with project to avoid impacts to sensitive cultural resources, facilitate tribal involvement, and establish baseline cultural resource sensitivity.

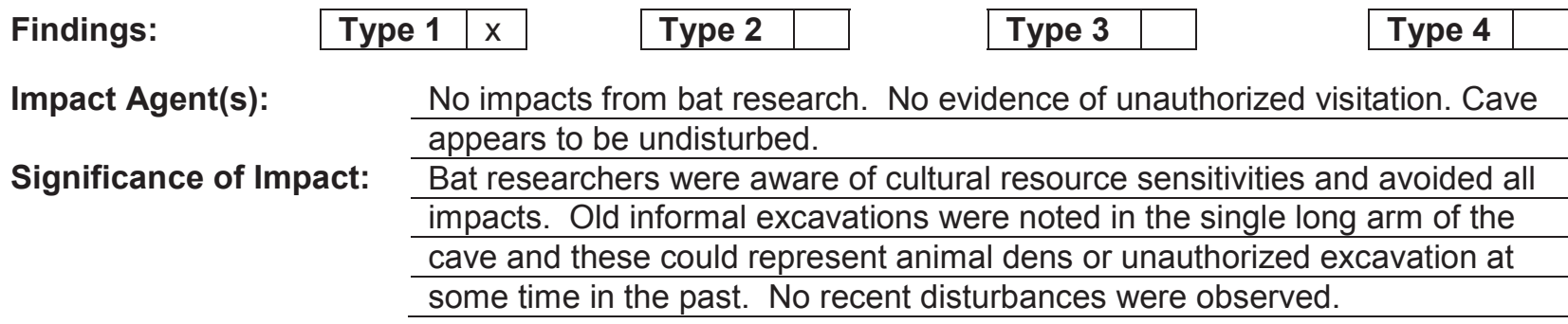

Did disturbance or impact extend into undisturbed areas?

Yes

No

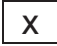

If yes, describe: No impacts observed.

Work Halted?

If yes, describe: N/A

Notifications: $\quad$ None required under Type I finding.

Primary Contact(s):

Date(s) Contacted:

Contact Method(s): | E-mail $\square$ Phone $\square$ Official correspondence, CCN\#:

Cultural Materials observed? Yes $\mathrm{x}$ No $\square$

If yes, describe: The North Tower Cave complex was recorded as an archaeological resource during a survey along Highway 20 in the 1980s. The underground portions of these lava tubes were not explored at this time, but extensive lithic scatters were documented around the cave entrances. A wooden plank and an obsidian flake were observed at the cave entrance and large mammal bones and possible sage torches were observed throughout the single arm during bat monitoring.

\begin{tabular}{llll} 
Cultural Materials Collected? No & Yes \\
\hline
\end{tabular}

If yes, describe:

General Comments: Cave affords stooped walk-in access to a single chamber $\sim 70 \mathrm{~m}$ in length. Soils were dry and dusty and quite deep as evidenced in several very large informal excavations. Most of these appeared to be animal dens, but they could also represent unauthorized looting for artifacts at some time in the past. Undisturbed deposits remain in the cave and these exhibit good potential for archaeological materials. 25 Townsends big eared bats were counted after the first ceiling constriction and this is also the area where the old excavations were present. Locational information withheld for resource protection.

Recommendations: $\quad$ Repeat visit, as allowed, for further evaluation of archaeological potential.

Attach additional documentation, as warranted (photos, profiles, etc.) $\quad$ Yes $\square$ No $\quad x$ If yes, describe: 
Idaho National Laboratory Cultural Resource Management Office

Field Monitoring Form

Monitor Number: 2013-Cave-15

Monitor Name(s): $\quad$ Hollie Gilbert, Julie B. Williams, Christina Olson, Carolyn Smith

Monitor Date: $\quad$ September 18, 2013

Project:

CRMO monitoring

Site Name/Number: $\quad$ Middle Butte Cave (10-BM-34)

Reason for monitoring: $\quad$ Required annual monitoring with Shoshone-Bannock tribal representatives.

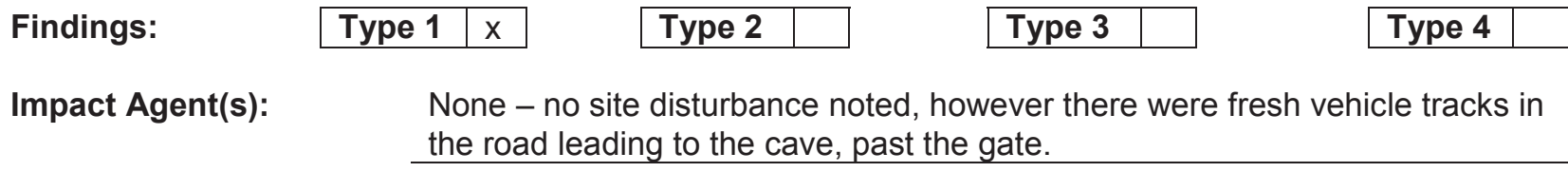

Significance of Impact: N/A

Did disturbance or impact extend into undisturbed areas?

Yes $\square$ No $\mathrm{x}$ If yes, describe:

Work Halted?

If yes, describe:

Yes $\square$ No $\mathrm{x}$

Notifications: N/A

Contact Method: $\quad$ E-mail $\quad \square$ Phone $\square$ Official correspondence, CCN\#:

$\begin{array}{llll}\text { Cultural Materials observed? } & \text { Yes } & x & \end{array}$

If yes, describe: Previously recorded surface artifacts are present across the site.

Cultural Materials collected?

Yes

No $\mathrm{x}$

If yes, describe: N/A

General Comments: Site appears to be stable. Cave was not entered this year due to DOE moratorium on cave entry. From the lip of the cave it appeared that there has been no foot traffic into cave. Gonzales-Stoller has installed bat detection equipment outside of the cave. It did appear that a vehicle has been driving past the gate to gain access to the cave. Per the concerns of Carolyn, our office contacted ecological research personnel to see if the tire tracks belong to them. Since then all research personnel have agreed to keep vehicle traffic outside of the gated area.

Recommendations: $\quad$ Continue to monitor annually. Discuss with INL security the possibility of installing surveillance equipment at the cave. 
Monitor Number: 2013-Cave-16

Monitor Name(s): $\quad$ Brenda Pace, Jericho Whiting, Bill Doering, Bryan Bybee, Quinn Shurtliff

Monitor Date:

September 24, 2013

Project:

Site Name/Number:

Bat research - Fall Mist Netting

Reason for monitoring:

Middle Butte Cave/10-BM-34

Observe and assist with project to avoid impacts to sensitive cultural resources and monitor cultural resources while minimizing cave entries to protect bats.

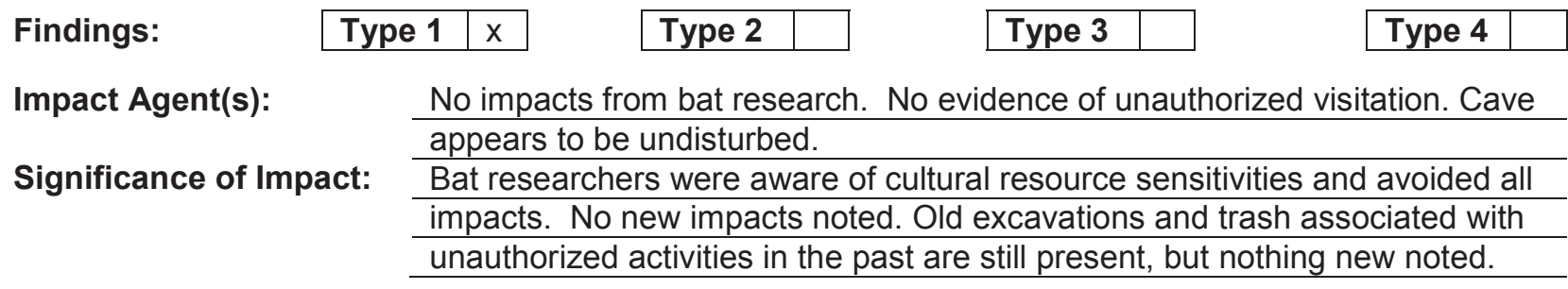

Did disturbance or impact extend into undisturbed areas?

Yes

No

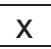

If yes, describe: No impacts observed.

Work Halted?

If yes, describe:

\section{Yes}

No

$\mathrm{N} / \mathrm{A}$

Notifications: $\quad$ None required under Type I finding.

Primary Contact(s):

Date(s) Contacted:

Contact Method(s): | E-mail $\quad$ Phone $\quad \mathrm{O}$ Official correspondence, CCN\#:

$\begin{array}{lllll}\text { Cultural Materials observed? } & \text { Yes } & x & \text { No }\end{array}$

If yes, describe: $\quad$ Middle Butte Cave is well-known for its cultural and archaeological significance. No new artifacts or rock art panels were observed and known materials exhibited no change. Notable cultural features are prehistoric rock art, historic and modern graffiti, fire rings, limited number of surface artifacts (large mammal bones, wood, occasional obsidian flakes).
Cultural Materials Collected?
Yes
No
$\mathrm{x}$

If yes, describe:

General Comments: All bat research activity during mist netting occurred in the crater associated with the entrance to Middle Butte Cave. None of the researchers entered the cave. INL Security personnel observed vehicle tracks in the snow out to the cave and drove out to cave to investigate the bat researchers and verify authorization. Mist nets were anchored to lightweight, telescoping plastic poles that were anchored in loose surface rocks and rope tie-offs to the rim rock. Disturbance was minimal. Two nets were stretched laterally across the crater, one near the mouth of the north arm and one near the center of the crater. Rock wrens were the first creatures captured and released. From 8pm to 10:30pm, 24 Townsends big eared bats and one hoary bat were captured, documented, and released. Locational information withheld for resource protection.

Recommendations: Continue routine monitoring of all activities at Middle Butte Cave. Assess future access and establish vehicle/parking protocols to reduce gate drive-arounds and associated surface impacts.

Attach additional documentation, as warranted (photos, profiles, etc.) If yes, describe: 
Monitor Number: 2013-Cave-17

Monitor Name(s): $\quad$ Brenda Pace, Hollie Gilbert

Monitor Date: $\quad$ October 17, 2013

Project:

Site Name/Number:

INL CRM Office Monitoring program

Aviators Cave/10-BT-1582

Reason for monitoring: Routine - annual visit with Shoshone-Bannock tribal representatives

Findings:

Impact Agent(s):

Significance of Impact:
Type 2

Type 3

Type 4
No new impacts observed. Animal traffic remains high with established game trails heading east toward water available at MFC. Bat monitoring equipment is present, but has not caused impacts. Footprints around

bat equipment and on new trail and road leading west from MFC. Old impacts from unauthorized surface artifact removal are still apparent, animal traffic continues, and bat monitoring equipment and routine visits continue, but no new impacts were noted to the cave and sensitive cultural artifacts. New access road presents greater potential for impacts.

Did disturbance or impact extend into undisturbed areas?

Yes

No

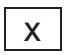

If yes, describe:

Work Halted?

No impacts observed.

If yes, describe:

\section{Yes}

N/A

No $\quad x$

Notifications: $\quad$ None required under Type I finding.

Primary Contact(s):

Date(s) Contacted:

Contact Method(s): | E-mail $\quad$ Phone $\square$ Official correspondence, CCN\#:

\section{$\begin{array}{llll}\text { Cultural Materials observed? } & \text { Yes } \mathrm{x} \text { No } \\ \end{array}$}

If yes, describe: $\quad$ Aviators Cave contains significant cultural resources and Shoshone-Bannock tribal values and is listed on the National Register of Historic Places. Surface artifacts are dense. Noted small side-notched point fragment, shaft straightener, and various small biface tools. Diagnostics were limited in quantity though. Two artifact piles attributed to vandals have not changed.

\section{$\begin{array}{llll}\text { Cultural Materials Collected? } & \text { Yes } \\ \end{array}$} If yes, describe:

General Comments: $\quad$ Cave remains undisturbed aside from looting of surface artifacts from 2009. New road leading from MFC is actually an old fire break. Game trails are very pronounced too. Cave does appear to be more vulnerable to unauthorized visitation now with the new "road." Locational information withheld for resource protection.

Recommendations: $\quad$ Continue routine monitoring of all activities at Aviators Cave. Assess future access and establish vehicle/parking protocols for ongoing bat research and to minimize unauthorized visitation. Consider installation of a camera at cave. Work with INL Roads and Grounds, Fire Dept., and MFC security to rehabilitate fire break/"road" and issue notice to MFC population that area is off limits.

Attach additional documentation, as warranted (photos, profiles, etc.)

Yes

No $x$ If yes, describe: 
A: Prehistoric Archaeological Sites 
Monitor Number: 2013-PH-1

Monitor Name: $\quad$ Brenda Pace, Hollie Gilbert, National Security Test Range personnel

Monitor Date(s): May 21, 2013

Project: $\quad$ N/A

Site Name/Number: $\quad$ 10-JF-88/Hellofasite

Reason for Monitoring: Routine surveillance of significant archaeological sites

Findings:

\begin{tabular}{|l|l|}
\hline Type 1 & $\mathrm{x}$ \\
\hline
\end{tabular}

Type 2

Type 3

Type 4

Impact Agent(s): $\quad$ Wind erosion, animal burrowing.

Significance of Impact: No new impacts were noted. Wind continues to influence surface soils throughout the site area, exposing new artifacts and covering others. Animal burrows are showing up in soft, sandy soils. Rock walls appear unharmed from nearby explosive testing. Previously reported evidence of Type 3 impacts is still apparent. No new evidence of looting was discovered. In spite of past impacts the site retains archaeological and cultural significance and potential for future research.

Did disturbance or impact extend into undisturbed areas? $\quad$ Yes $\quad$\begin{tabular}{l|l|l|l|} 
No & $\mathrm{x}$ \\
\hline
\end{tabular} If yes, describe: N/A

Work Halted? Yes $\square$ No $\mathrm{x}$

If yes, describe:

Notifications: $\quad$ None required under Type 1 finding.

Date Contacted:

Contact Method: $\mid \overline{E-m a i l} \quad \square$ Phone $\longleftarrow$ Official correspondence, CCN\#:

Cultural Materials Observed? Yes $\mathrm{x}$ No

If yes, describe: In 1984 the site was named "Hellofasite" for the dense, diverse scatter of artifacts and unique rock walls recorded there. In FY 2011,, looters relocated many surface artifacts to distinct "discard piles" and removed previously documented diagnostic artifacts (numerous projectile points, pottery, scrapers, knives, etc.). In 2012, INL Power Management distributed a video that shows how heavy equipment disturbance occurred. In 2013, no new evidence of human-caused disturbance was apparent. Winds continue to influence surface soils on the site, exposing some artifacts and covering others. A few pieces of pottery and two small arrow point fragments are newly exposed.

Cultural Materials Collected? Yes $\square$ No $\mathrm{x}$ If yes, describe:

General Comments: Visual inspection of the site indicates no impacts to rock structures and no new impacts to surrounding assemblage of artifacts. Looting, human-caused disturbance, and powerline work have caused significant impacts in the past but were not active in 2013. Site retains potential for future research in spite of past impacts. Federal agents and DOE-ID continue an active investigation for vandals.

Recommendations: $\quad$ Continue routine monitoring and implement recommendations arising from ongoing federal investigation, as appropriate.

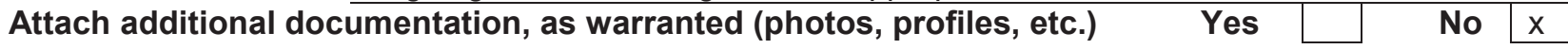




\section{A: Historic Archaeological Sites}


Idaho National Laboratory Cultural Resource Management Office

Field Monitoring Form

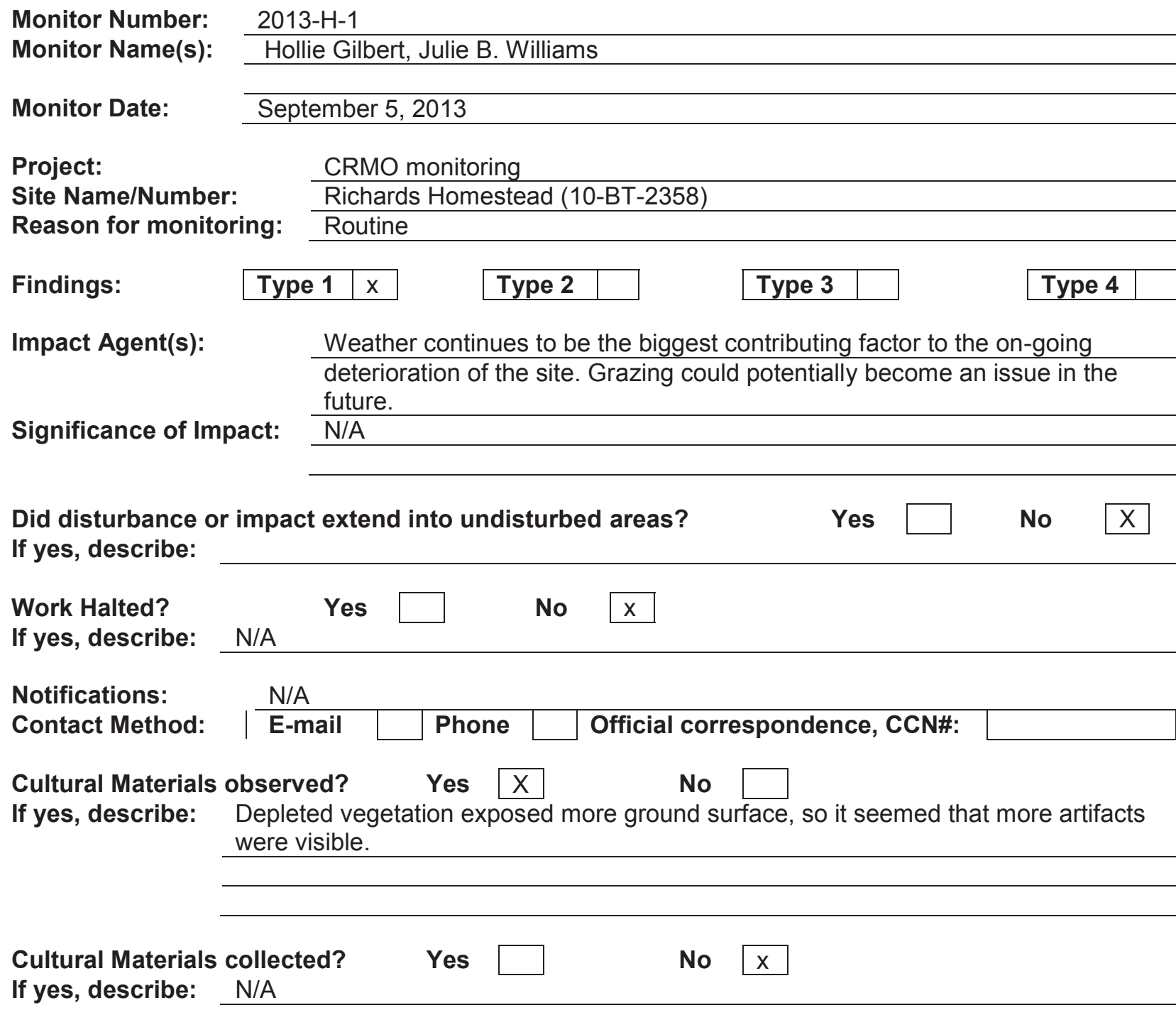

General Comments: Tire marks across the site were observed, but no impacts were noted. Site saw both sheep and cattle grazing activity this year. Soils and vegetation have been disturbed/churned, however the integrity of the site remains intact.

Recommendations: $\quad$ Site should be monitored annually due to its proximity to public lands. 
Idaho National Laboratory Cultural Resource Management Office Field Monitoring Form

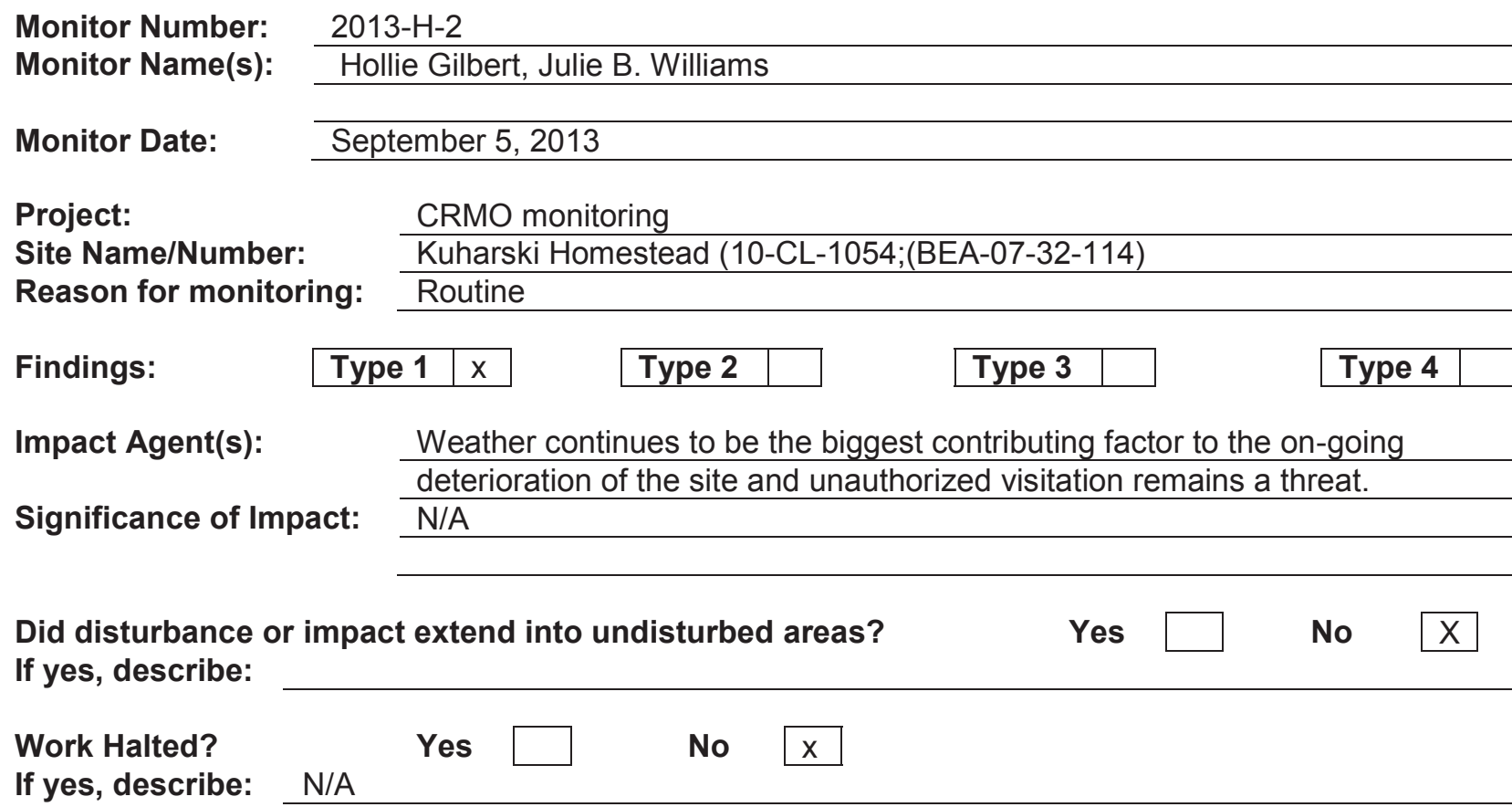

Notifications: N/A

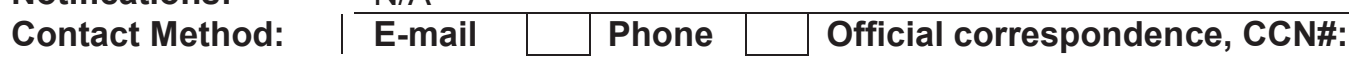

Cultural Materials observed? Yes $X$ No $\square$

If yes, describe: As per previous monitoring, visitations and recordings, cultural materials remain intact and expected artifacts are found across site.

Cultural Materials collected? Yes $\square$ No $\quad x$

If yes, describe: N/A

General Comments: The badger activity within the forge area from a few years ago seems to have subsided. No grazing occurred over site this year.

Recommendations: $\quad$ Site should be monitored annually due to its proximity to public lands. 
Idaho National Laboratory Cultural Resource Management Office Field Monitoring Form

$\begin{array}{ll}\text { Monitor Number: } & 2013-\mathrm{H}-3 \\ \text { Monitor Name(s): } & \text { Hollie Gilbert, Julie B. Williams, Christina Olson }\end{array}$

Monitor Date: $\quad$ August 22, 2013

Project: $\quad$ CRMO monitoring

Site Name/Number: $\quad$ Powell Stage Station (10-BT-2194)

Reason for monitoring: Routine

\begin{tabular}{l|l|l|l|l|}
\hline Findings: & Type 1 & Type 2 & $\mathrm{x}$
\end{tabular}$\quad$\begin{tabular}{|l|l|l|}
\hline Type 3 & \\
\hline
\end{tabular}

Impact Agent(s): $\quad$ Rodent Burrowing

Significance of Impact: $\quad$ Burrows are located at the SE and SW corners of the basalt foundation. It appears that possibly part of the SE corner has tumbled.

Did disturbance or impact extend into undisturbed areas?

Yes

No

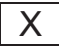

If yes, describe:

Work Halted?

If yes, describe:

Yes

No $x$

Notifications:

Contact Method:

N/A

Cultural Materials observed? Phone Official correspondence, CCN\#:

If yes, describe:

Yes $X$

No

As per previous monitoring, visitations and recordings, cultural materials remain intact and expected artifacts are found across site.

Cultural Materials collected?

Yes

No $x$

If yes, describe: N/A

General Comments: Rodent burrows have been a concern at this site in the past, however they appear to be more threatening to the structural integrity of the basalt foundation. We will contact a biologist at Gonzales-Stoller for possible solutions to the rodent problem.

Recommendations: $\quad$ Site should be monitored annually. 
Idaho National Laboratory Cultural Resource Management Office Field Monitoring Form

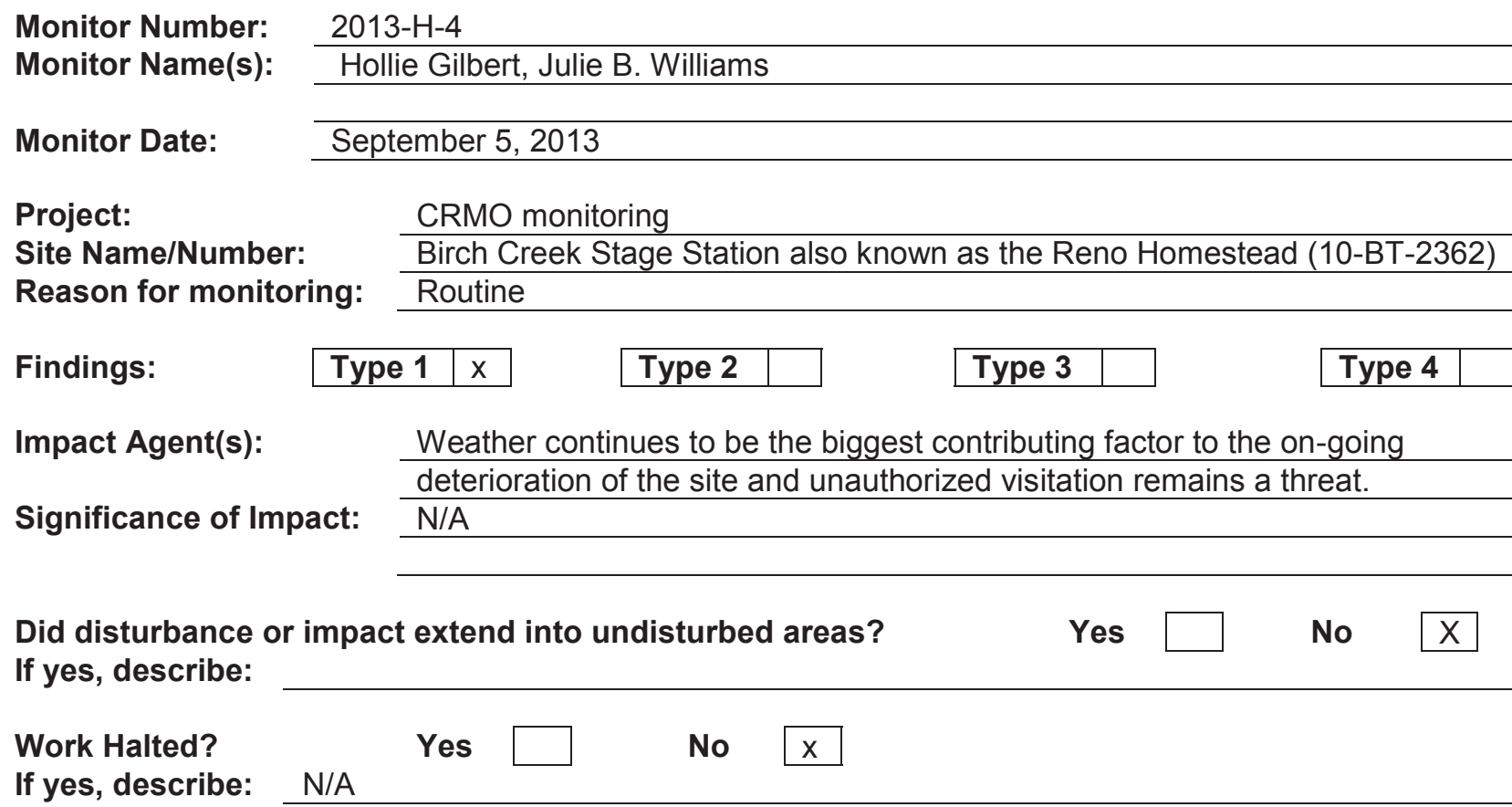

Notifications: $\quad$ N/A

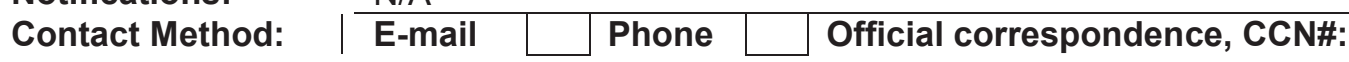

Cultural Materials observed? Yes $\mathrm{X}$ No $\quad$ ?

If yes, describe: $\quad$ As per previous monitoring, visitations and recordings, cultural materials remain intact and undisturbed and general expected artifacts are found across the site.

Cultural Materials collected? Yes $\square$ No $\quad x$

If yes, describe: N/A

General Comments: This location has been used by sheepherders in the past, but the area was not camped in this year, nor is grazing apparent.

Recommendations: $\quad$ Site should be monitored annually due to its proximity to public lands. 
A: Historic Trails 
Idaho National Laboratory Cultural Resource Management Office Field Monitoring Form

Monitor Number: $\quad$ 2013-HT-1

Monitor Name(s): $\quad$ Hollie Gilbert, Julie B. Williams, Christina Olson

Monitor Date: $\quad$ August 12, 2013

Project: $\quad$ CRMO monitoring

Site Name/Number: $\quad$ Goodale's Cutoff (Oregon Trail)

Reason for monitoring: Routine

Findings:

\begin{tabular}{|l|l|}
\hline Type 1 & $\mathrm{x}$ \\
\hline
\end{tabular}

Type 2

Type 3

Type 4

Impact Agent(s): $\quad$ Natural erosion and cattle ranching activities continue to be the biggest contributing factor to the on-going deterioration of the road.

Significance of Impact: N/A

Did disturbance or impact extend into undisturbed areas?

If yes, describe:

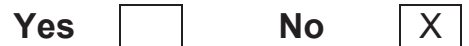

Work Halted?

If yes, describe:

No $x$

Notifications: $\quad$ N/A

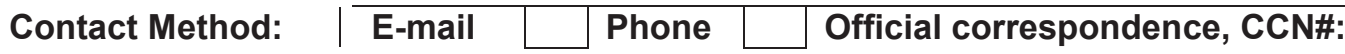

Cultural Materials observed? Yes $\mathrm{X}$ No

If yes, describe:

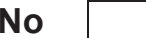

\section{Cultural Materials collected? Yes $\square$ No $\quad \mathrm{X}$}

If yes, describe: N/A

General Comments: It appears that this trail has not been as heavily used by cattle ranchers this year as it has in past years.

Recommendations: $\quad$ Site should be monitored annually due to its proximity to public lands and historical significance. 
A: Modern Resources 
Idaho National Laboratory Cultural Resource Management Office

Field Monitoring Form

Monitor Name(s):

Julie Williams and Hollie Gilbert

Monitor Date: $\quad$ June 5, 2013

Project: $\quad$ EBR I Reactor Building and Guardhouse

Site Name/Number: $\quad$ EBR-601 and EBR-602

Reason for monitoring: $\quad$ Routine surveillance of INL historic properties

Findings:

Type 1

Type 2 1 X

Type 3

Type 4

Impact Agent(s): $\quad$ Moisture, lack of maintenance; existing impacts previously reported, no new impacts

Significance of Impact: $\quad$ EBR-601 - Does not impact National Historic Landmark status. EBR-602 Does not impact eligibility to the National Register of Historic Places

\begin{tabular}{|ll|l|l|} 
Did disturbance or impact extend into undisturbed areas? & Yes & No & No
\end{tabular} If yes, describe: N/A

Work Halted?

If yes, describe: N/A

Notifications: $\quad$ N/A

\begin{tabular}{l|l|l|l|l|l} 
Contact Method: & E-mail & & Phone & & Official correspondence, CCN\#:
\end{tabular}

Cultural Materials observed? Yes $\mathrm{X}$ No $\square$

If yes, describe: The EBR I Reactor Building is a National Historic Landmark and its associated guardhouse is eligible for listing on the National Register of Historic Places.

Cultural Materials collected?

Yes

No $x$

If yes, describe: N/A

General Comments: Visual inspection of the concrete foundation and bricks and mortar indicates some spalling and deterioration from moisture on EBR-601. EBR-602 shows roof shingle and clapboard deterioration from lack of routine maintenance.

Recommendations: $\quad$ Install adequate external drainage system on EBR-601 and perform minimal routine maintenance on EBR-602.

Attach additional documentation, as warranted (photos, profiles, etc.)

Yes

No $x$

If yes, describe: Photos of deterioration 
Idaho National Laboratory Cultural Resource Management Office

Field Monitoring Form

Monitor Name(s):

Julie Williams and Hollie Gilbert

Monitor Date:

June 19, 2013

Project:

CFA World War II Marine Barracks

Site Name/Number:

CFA-606

Reason for monitoring: $\quad$ Routine surveillance of INL historic properties

Findings:

\begin{tabular}{|l|l|}
\hline Type 1 & \\
\hline
\end{tabular}

\begin{tabular}{|l|l|}
\hline Type 2 & $\mathrm{X}$ \\
\hline
\end{tabular}

Type 3

Type 4

Impact Agent(s): $\quad$ Moisture, lack of maintenance; existing impacts previously reported, no new impacts

Significance of Impact: $\quad$ Does not impact National Historic eligibility status

Did disturbance or impact extend into undisturbed areas?

If yes, describe: $\mathrm{N} / \mathrm{A}$

Yes $\square$ No $\mathrm{X}$

Work Halted?

If yes, describe: $\quad \mathrm{N} / \mathrm{A}$

Notifications: $\quad$ N/A

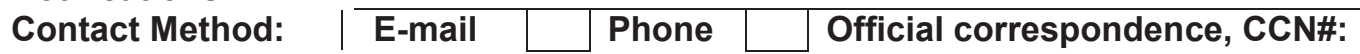

Cultural Materials observed? Yes $\mathrm{X}$ No $\square$

If yes, describe: CFA-606 is eligible for listing on the National Register of Historic Places.

Cultural Materials collected? Yes $\square$ No $\mathrm{x}$

If yes, describe: N/A

General Comments: Visual inspection of the building's historic features indicates some spalling of concrete and overall general deterioration from moisture and lack of routine maintenance and repair.

Recommendations: $\quad$ None. Building is scheduled for demolition and consultation between SHPO, ACHP, and DOE-ID is ongoing.

Attach additional documentation, as warranted (photos, profiles, etc.)

Yes

No $x$

If yes, describe: Photos on file 
Idaho National Laboratory Cultural Resource Management Office

Field Monitoring Form

Monitor Number: $\quad$ 2013-MR-3

Monitor Name(s): Julie Williams and Hollie Gilbert

Monitor Date: $\quad$ June 19, 2013

Project: $\quad$ CFA World War II Officer's Quarters

Site Name/Number: $\quad$ CFA-607

Reason for monitoring: $\quad$ Routine surveillance of INL historic properties

\begin{tabular}{l|l|l|l|l|l|}
\hline Findings: & Type 1 & Type 2 & $\mathrm{X}$ & Type 3 & \\
\hline
\end{tabular}

Impact Agent(s): $\quad$ Moisture, lack of maintenance; existing impacts previously reported, no new

$\begin{array}{ll} & \text { impacts } \\ \text { Significance of Impact: } & \text { Does not impact National Historic eligibility status }\end{array}$

\begin{tabular}{lll|l|} 
Did disturbance or impact extend into undisturbed areas? & Yes & No & $\mathrm{X}$ \\
\hline
\end{tabular}

If yes, describe: N/A

Work Halted? Yes $\square$ No $\square$

If yes, describe: N/A

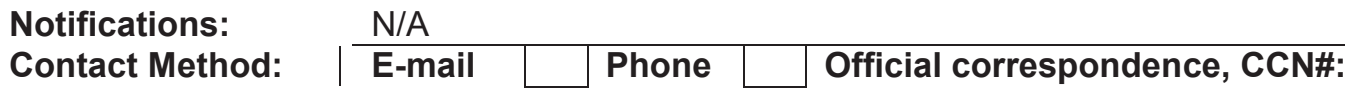

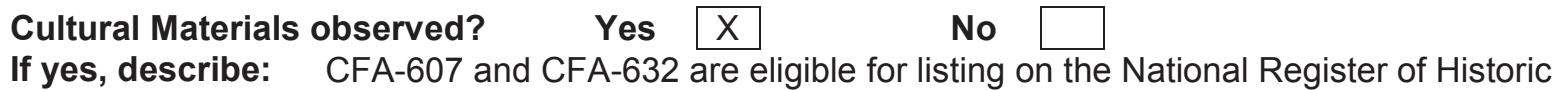
Places.

Cultural Materials collected? Yes $\square$ No $\mathrm{X}$

If yes, describe: N/A

General Comments: Visual inspection of the building's historic features indicates some spalling of concrete and overall general deterioration from moisture and lack of routine maintenance and repair.

Recommendations: $\quad$ None. Building is scheduled for demolition and consultation between SHPO, ACHP, and DOE-ID is ongoing.

Attach additional documentation, as warranted (photos, profiles, etc.) $\quad$ Yes $\square$ No $\quad x$ If yes, describe: Photos on file 
Idaho National Laboratory Cultural Resource Management Office

Field Monitoring Form

Monitor Number: $\quad$ 2013-MR-4

Monitor Name(s): Julie Williams and Hollie Gilbert

Monitor Date: $\quad$ June 19, 2013

Project:

CFA World War II Officer's Garage

Site Name/Number: $\quad$ CFA-632

Reason for monitoring: $\quad$ Routine surveillance of INL historic properties

\begin{tabular}{l|l|l|l|l|l|}
\hline Findings: & Type 1 & Type 2 & $\mathrm{X}$ & Type 3 & \\
\hline
\end{tabular}

Impact Agent(s): $\quad$ Moisture, lack of maintenance; existing impacts previously reported, no new impacts

Significance of Impact: $\quad$ Does not impact National Historic eligibility status

Did disturbance or impact extend into undisturbed areas?

Yes $\square$ No $\mathrm{X}$

If yes, describe: N/A

Work Halted?

If yes, describe: N/A

Notifications: $\quad$ N/A

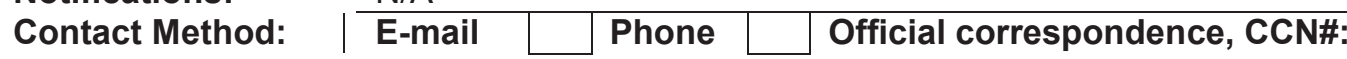

Cultural Materials observed? Yes $\mathrm{X}$ No $\square$

If yes, describe: CFA-632 is eligible for listing on the National Register of Historic Places.

\section{Cultural Materials collected? Yes $\square$ No $\quad \mathrm{X}$}

If yes, describe: N/A

General Comments: Visual inspection of the building's historic features indicates some spalling of concrete and overall general deterioration from moisture and lack of routine maintenance and repair.

Recommendations: $\quad$ None. Building is scheduled for demolition and consultation between SHPO, $A C H P$, and DOE-ID is ongoing.

Attach additional documentation, as warranted (photos, profiles, etc.)

Yes

No $x$ If yes, describe: Photos on file 
Idaho National Laboratory Cultural Resource Management Office

Field Monitoring Form

Monitor Name(s):

Julie Williams and Hollie Gilbert

Monitor Date:

June 19, 2013

Project:

CFA World War II Officer's Quarters

Site Name/Number:

CFA-613

Reason for monitoring: $\quad$ Routine surveillance of INL historic properties

Findings:

\begin{tabular}{|l|l|}
\hline Type 1 & \\
\hline
\end{tabular}

\begin{tabular}{|l|l|}
\hline Type 2 & $\mathrm{X}$ \\
\hline
\end{tabular}

\begin{tabular}{|l|l|}
\hline Type 3 & \\
\hline
\end{tabular}

Type 4

Impact Agent(s): $\quad$ Moisture, lack of maintenance; existing impacts previously reported, no new impacts

Significance of Impact: $\quad$ Does not impact National Historic eligibility status

Did disturbance or impact extend into undisturbed areas?

If yes, describe: $\mathrm{N} / \mathrm{A}$

Yes $\square$ No $\mathrm{X}$

Work Halted?

If yes, describe: N/A

Notifications: $\quad$ N/A

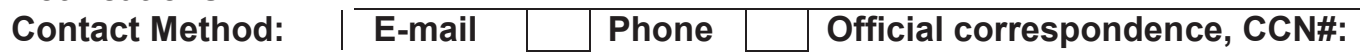

Cultural Materials observed? Yes $\mathrm{X}$ No $\square$

If yes, describe: CFA-613 is eligible for listing on the National Register of Historic Places.

Cultural Materials collected? Yes $\square$ No $\mathrm{x}$

If yes, describe: N/A

General Comments: Visual inspection of the building's historic features indicates some spalling of concrete and overall general deterioration from moisture and lack of routine maintenance and repair.

Recommendations: $\quad$ None. Building is scheduled for demolition and consultation between SHPO, ACHP, and DOE-ID is ongoing.

Attach additional documentation, as warranted (photos, profiles, etc.)

Yes

No $x$

If yes, describe: Photos on file 
Idaho National Laboratory Cultural Resource Management Office

Field Monitoring Form

Monitor Number: $\quad$ 2013-MR-6

Monitor Name(s): Julie Williams and Hollie Gilbert

Monitor Date: $\quad$ June 19, 2013

Project:

CFA World War II Proofing Area

Site Name/Number: $\quad$ CFA-633

Reason for monitoring: $\quad$ Routine surveillance of INL historic properties

\begin{tabular}{l|l|l|l|l|}
\hline Findings: & Type 1 & Type 2 & $\mathrm{X}$ & Type 3 \\
\hline
\end{tabular}

Impact Agent(s): $\quad$ Moisture, lack of maintenance; existing impacts previously reported, no new impacts

Significance of Impact: $\quad$ Does not impact National Historic eligibility status

Did disturbance or impact extend into undisturbed areas?

If yes, describe: N/A

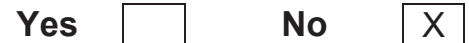

Work Halted?

If yes, describe: N/A

Notifications: $\quad$ N/A

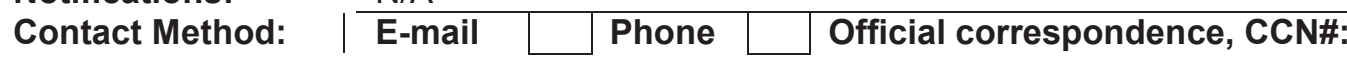

Cultural Materials observed? Yes $\mathrm{X}$ No $\square$

If yes, describe: CFA-633 is eligible for listing on the National Register of Historic Places.

\section{Cultural Materials collected? Yes $\square$ No $\quad \mathrm{X}$}

If yes, describe: N/A

General Comments: Visual inspection of the building's historic features indicates some spalling of concrete and overall general deterioration from moisture and lack of routine maintenance and repair.

Recommendations: $\quad$ Continue to monitor condition. Demolition of non-original features is scheduled and consultation between SHPO, ACHP, and DOE-ID is ongoing. Following features' demolition, minor maintenance is recommended (i.e., weed control).

Attach additional documentation, as warranted (photos, profiles, etc.)

Yes

No $x$ If yes, describe: Photos on file 
Idaho National Laboratory Cultural Resource Management Office

Field Monitoring Form

Monitor Number: $\quad$ 2013-MR-7

Monitor Name(s): $\quad$ Julie Williams and Hollie Gilbert

Monitor Date: $\quad$ June 19, 2013

Project: $\quad$ CFA World War II Ammunition Storage Bunkers

Site Name/Number: $\quad$ CFA-637

Reason for monitoring: $\quad$ Routine surveillance of INL historic properties

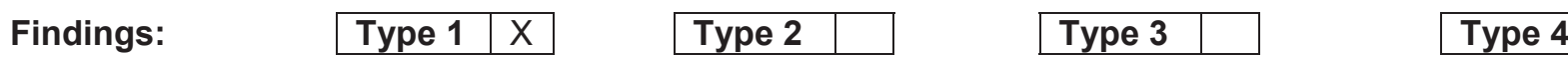

Impact Agent(s): $\quad$ No visible impacts.

Significance of Impact: $\quad$ N/A

Did disturbance or impact extend into undisturbed areas?

If yes, describe: N/A

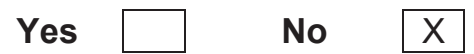

Work Halted?

Yes $\square$ No $\mathrm{X}$

If yes, describe: N/A

Notifications: N/A

Contact Method: $\quad$ | E-mail $\quad \square$ Phone $\quad \square$ Official correspondence, CCN\#:

$\begin{array}{lllll}\text { Cultural Materials observed? } & \text { Yes } & \mathrm{X} & \end{array}$

If yes, describe: CFA-637 is eligible for listing on the National Register of Historic Places.

Cultural Materials collected?

Yes $\square$ No $x$

If yes, describe: N/A

General Comments: The structure is still in use and receiving minimal maintenance.

Recommendations: N/A

Attach additional documentation, as warranted (photos, profiles, etc.)

Yes

No $x$

If yes, describe: 
Idaho National Laboratory Cultural Resource Management Office

Field Monitoring Form

Monitor Number: $\quad$ 2013-MR-8

Monitor Name(s): $\quad$ Julie Williams and Hollie Gilbert

Monitor Date: $\quad$ June 19, 2013

Project: $\quad$ CFA World War II Ammunition Storage Bunkers

Site Name/Number: $\quad$ CFA-638

Reason for monitoring: $\quad$ Routine surveillance of INL historic properties

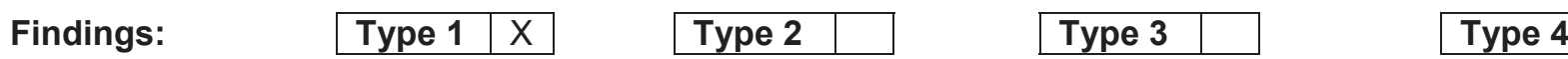

Impact Agent(s): $\quad$ Minimal maintenance performed.

Significance of Impact: $\quad$ N/A

Did disturbance or impact extend into undisturbed areas?

Yes No No

If yes, describe: N/A

Work Halted? Yes $\square$ No $\quad$ X

If yes, describe: $\quad \mathrm{N} / \mathrm{A}$

Notifications: N/A

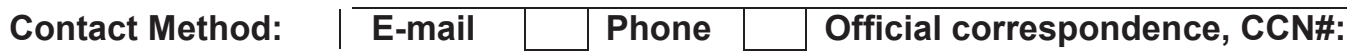

Cultural Materials observed? Yes $\mathrm{X}$ No $\square$

If yes, describe: CFA-638 is eligible for listing on the National Register of Historic Places.

Cultural Materials collected? Yes $\square$ No $\mathrm{X}$

If yes, describe: N/A

General Comments: The structure is still in use and receiving minimal maintenance. Some minor concrete spalling.

Recommendations: N/A

Attach additional documentation, as warranted (photos, profiles, etc.) If yes, describe: 
Idaho National Laboratory Cultural Resource Management Office

Field Monitoring Form

Monitor Number: $\quad$ 2013-MR-9

Monitor Name(s): Julie Williams and Hollie Gilbert

Monitor Date: $\quad$ June 19, 2013

Project: $\quad$ CFA World War II Pumphouses

Site Name/Number: $\quad$ CFA-642

Reason for monitoring: $\quad$ Routine surveillance of INL historic properties
Findings:
\begin{tabular}{|l|l|}
\hline Type 1 & $\mathrm{X}$ \\
\hline
\end{tabular}
Type 2
Type 3
Type 4

Impact Agent(s): $\quad$ No impacts have occurred

Significance of Impact: $\quad$ N/A

Did disturbance or impact extend into undisturbed areas?

If yes, describe: N/A

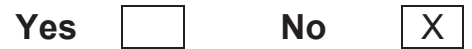

Work Halted?

If yes, describe: N/A

Notifications: $\quad$ N/A

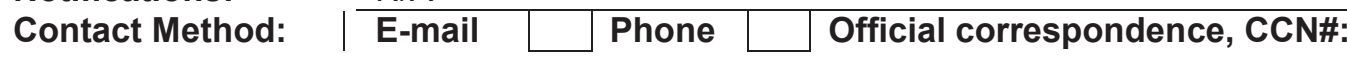

Cultural Materials observed? Yes $\mathrm{X}$ No $\square$

If yes, describe: CFA-642 is eligible for listing on the National Register of Historic Places.

Cultural Materials collected? Yes $\square$ No $\mathrm{x}$

If yes, describe: N/A

General Comments: The pumphouse is still in use and being maintained at a minimal level.

Recommendations: N/A

Attach additional documentation, as warranted (photos, profiles, etc.)

Yes $\square$ No $\mathrm{x}$ If yes, describe: 
Idaho National Laboratory Cultural Resource Management Office

Field Monitoring Form

Monitor Number: $\quad$ 2013-MR-10

Monitor Name(s): $\quad$ Julie Williams and Hollie Gilbert

Monitor Date: $\quad$ June 19, 2013

Project: $\quad$ CFA World War II Pumphouses

Site Name/Number: $\quad$ CFA-651

Reason for monitoring: $\quad$ Routine surveillance of INL historic properties

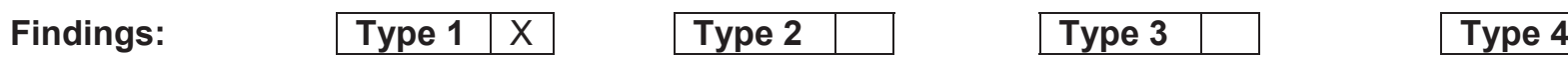

Impact Agent(s): $\quad$ No impacts have occurred

Significance of Impact: N/A

Did disturbance or impact extend into undisturbed areas?

Yes No No

If yes, describe: N/A

Work Halted?

If yes, describe:

Yes $\square$ No

Notifications: $\quad$ N/A

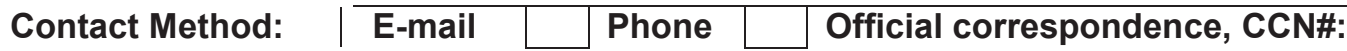

$\begin{array}{lllll}\text { Cultural Materials observed? } & \text { Yes } & \mathrm{X} & \end{array}$

If yes, describe: CFA-651 is eligible for listing on the National Register of Historic Places.

Cultural Materials collected? Yes $\square$ No $\quad x$

If yes, describe: N/A

General Comments: The pumphouse is still in use and being maintained at a minimal level.

Recommendations: N/A

Attach additional documentation, as warranted (photos, profiles, etc.)

Yes

No $x$

If yes, describe: 


\section{A: Projects}


Monitor Number:
Monitor Name(s):
Monitor Date:

2013-Project-1

Brenda Pace, Kip Winter, Kevin Brown

October 25, 2012

Project:

Expansion and ongoing operations at the Monroe Gravel Pit

Site Name/Number: 10-BT-1996

Reason for monitoring:

Re-identify site area to facilitate avoidance during proposed expansion of gravel pit

Findings:

\begin{tabular}{|l|l|}
\hline Type 1 & $\mathrm{X}$ \\
\hline
\end{tabular}

Type 2

Type 3

Type 4

Impact Agent(s):

Natural agents of range fire, wind erosion, and animal burrowing

Significance of Impact:

Impacts are light and not adverse. Range fire in early 2000s has resulted in some soil erosion and re-deposition. Animal burrows are visible. Artifacts originally noted at the site during initial recording in 1994 and re-visit in 2009 appear essentially unchanged.

Did disturbance or impact extend into undisturbed areas? Yes $\square$ No $\mathrm{x}$ If yes, describe: Site remains undisturbed by INL activities. Range fire has caused light erosion of surface soils. Animal burrows are present.

Work Halted?

If yes, describe:

Yes

No $\mathrm{x}$

Notifications:

Primary Contact(s):

Date(s) Contacted:

Contact Method(s): | E-mail $\square$ Phone $\square$ Official correspondence, CCN\#:

Cultural Materials observed?

Yes $\mathrm{x}$

No

If yes, describe: $\quad$ Artifact assemblage is similar to that reported in 1994 during initial recording. In 2013, approximately 15 flakes were observed along with a few fragments of firecracked rock that indicate a fire hearth may be present. Burned bone and tooth enamel present. Desert Side-notched point fragment observed in 2009 was not re-identified and may be covered with thin layer of re-deposited surface sand.

Cultural Materials Collected? Yes $\square$ No $\mathrm{X}$ If yes, describe: N/A

General Comments: No substantial changes from original recording. Gravel pit margin is moving closer to the site boundary, but landlord organization is aware of the sensitive resource and the need to avoid impacts.

Recommendations: Continue yearly monitoring, particularly during gravel pit expansion, and ensure that site is avoided when new road is established around the pit. Consider future test excavations to determine if resource contains significant subsurface cultural deposits.

Attach additional documentation, as warranted (photos, profiles, etc.) 
Monitor Number: 2013-Project-2

Monitor Name(s): $\quad$ Brenda R. Pace, Julie Williams, Christina Olson, Carolyn Smith, Romelia Martinez

Monitor Date:

April 2, 2013 and April 17, 2013

Project: $\quad$ Resumption of Transient Testing at INL Materials and Fuels Complex

Site Name/Number: $\quad$ 10-BM-223

Reason for monitoring: Re-identify site area to facilitate avoidance during proposed project.

\begin{tabular}{l|l|l|l|l|}
\hline Findings: & Type 1 & $\mathrm{x}$
\end{tabular}$\quad$\begin{tabular}{|l|l|}
\hline Type 2 &
\end{tabular}$\quad$\begin{tabular}{|l|l|}
\hline Type 3 4 \\
\hline
\end{tabular}

Impact Agent(s): $\quad$ Natural agents of range fire and wind erosion; firebreaks in vicinity

Significance of Impact: $\quad$ Repeated range fires over the site area and in the vicinity have removed established vegetation and increased erosion and aeolian re-deposition of surface soils throughout the area. Artifacts originally noted at the site during original recording in 1988 appear to be largely covered by an extensive dune-like deposit of sandy soil. Firebreaks have been established in the vicinity, but appear to have missed the majority of artifacts. Overall, impacts are not adverse. Undisturbed cultural deposits remain and may be protected by the new deposit of soil.

Did disturbance or impact extend into undisturbed areas?

If yes, describe: $\quad \mathrm{N} / \mathrm{A}$

\begin{tabular}{llll} 
Work Halted? & Yes \\
If yes, describe: & N/A & No & $\mathrm{X}$ \\
\hline
\end{tabular}

Notifications: $\quad$ None required under Type I finding.

Primary Contact(s):

Date(s) Contacted:

Contact Method(s): | E-mail $\square$ Phone $\square$ Official correspondence, CCN\#:

Cultural Materials observed? Yes $\mathrm{x}$ No

If yes, describe: Many of the 30 artifacts observed in 1988 are now covered by a recent deposit of aeolian sandy soil. In 2013, the visible surface artifact inventory included only five obsidian flakes. No diagnostic stone tools or evidence of possible fire hearths was evident on the current ground surface. One old pin flag was found.

Cultural Materials Collected? Yes $\square$ No $\mathrm{X}$

If yes, describe: N/A

General Comments: Site is located in an undeveloped area surrounding the TREAT facility, where project activities are unlikely. Newly deposited aeolian soil is covering artifacts and probably providing some protection for them. As work at the TREAT facility is re-started, overall levels of activity in the area will likely increase.

Recommendations: The site should be periodically monitored for evidence of soil disturbance (i.e., offroad vehicle use, mowing, erosion) as well as unauthorized visitation and/or artifact removal. This is also consistent with tribal concerns raised during a tour of the project area.

Attach additional documentation, as warranted (photos, profiles, etc.) Yes No $x$ If yes, describe: 
Monitor Number: 2013-Project-3

Monitor Name(s): $\quad$ Brenda Pace, Julie Williams, Christina Olson, John Irving

Monitor Date: $\quad$ April 2, 2013

Project: $\quad$ National and Homeland Security Powerline Testing

Site Name/Number: $\quad$ BEA-08-29-02

Reason for monitoring: Routine check on project compliance with cultural resource recommendations

Findings: $\quad$\begin{tabular}{|l|l|l|l|}
\hline Type 1 & $\mathrm{x}$
\end{tabular}$\quad$\begin{tabular}{|l|l|}
\hline Type 2 &
\end{tabular}$\quad$\begin{tabular}{|l|l|} 
Type 3 & \\
\hline
\end{tabular}

Impact Agent(s): $\quad$ No new impacts observed. As noted during original recording in 2008, site has been impacted by construction of the powerline and unauthorized artifact removal many years ago

Significance of Impact: $\quad$ No new impacts observed. Project has restricted all activities to existing road through sensitive site area in compliance with original cultural resource recommendations.

Did disturbance or impact extend into undisturbed areas? Yes $\square$ No

If yes, describe: Project is in compliance with cultural resource recommendations to restrict all work activities to existing roads and narrow zones surrounding existing power poles.

Work Halted? Yes No $\square$ No

If yes, describe: $\quad$ Project is in compliance with recommendations for cultural resource protection.

Notifications: $\quad$ None required under Type I finding.

Primary Contact(s):

Date(s) Contacted:

Contact Method(s): | E-mail $\square$ Phone $\square$ Official correspondence, CCN\#:

Cultural Materials observed? Yes $x$ No $\square$

If yes, describe: Artifact assemblage is unchanged from the original recording in 2008. The site is a dense scatter of debitage, burned bone, chipped stone tools, ground stone, and firecracked rock. Buried hearth features and other subsurface cultural deposits are highly likely. Several looter discard piles are present, indicating that unauthorized artifact removal has occurred in the past. Diagnostics are numerous though, including biface fragments, drills, a fragmentary grinding slab, Elko Corner-notched point, large stone blades, and a shaft straightener.

Cultural Materials Collected? Yes $\square$ No $\mathrm{x}$ If yes, describe: N/A

General Comments: No substantial changes from original recording. Project is in compliance with cultural resource recommendations and site is not being impacted. Old evidence of unauthorized artifact removal is notable and may be part of larger pattern of looting behavior associated with powerlines on the INL.

Recommendations: $\quad$ Continue periodic monitoring of all projects in and around the PBF/CITRC area. Investigate possible pattern of looting associated with powerlines on INL and if substantiated, initiate targeted employee education of associated personnel.

Attach additional documentation, as warranted (photos, profiles, etc.)

Yes No $x$ If yes, describe: 


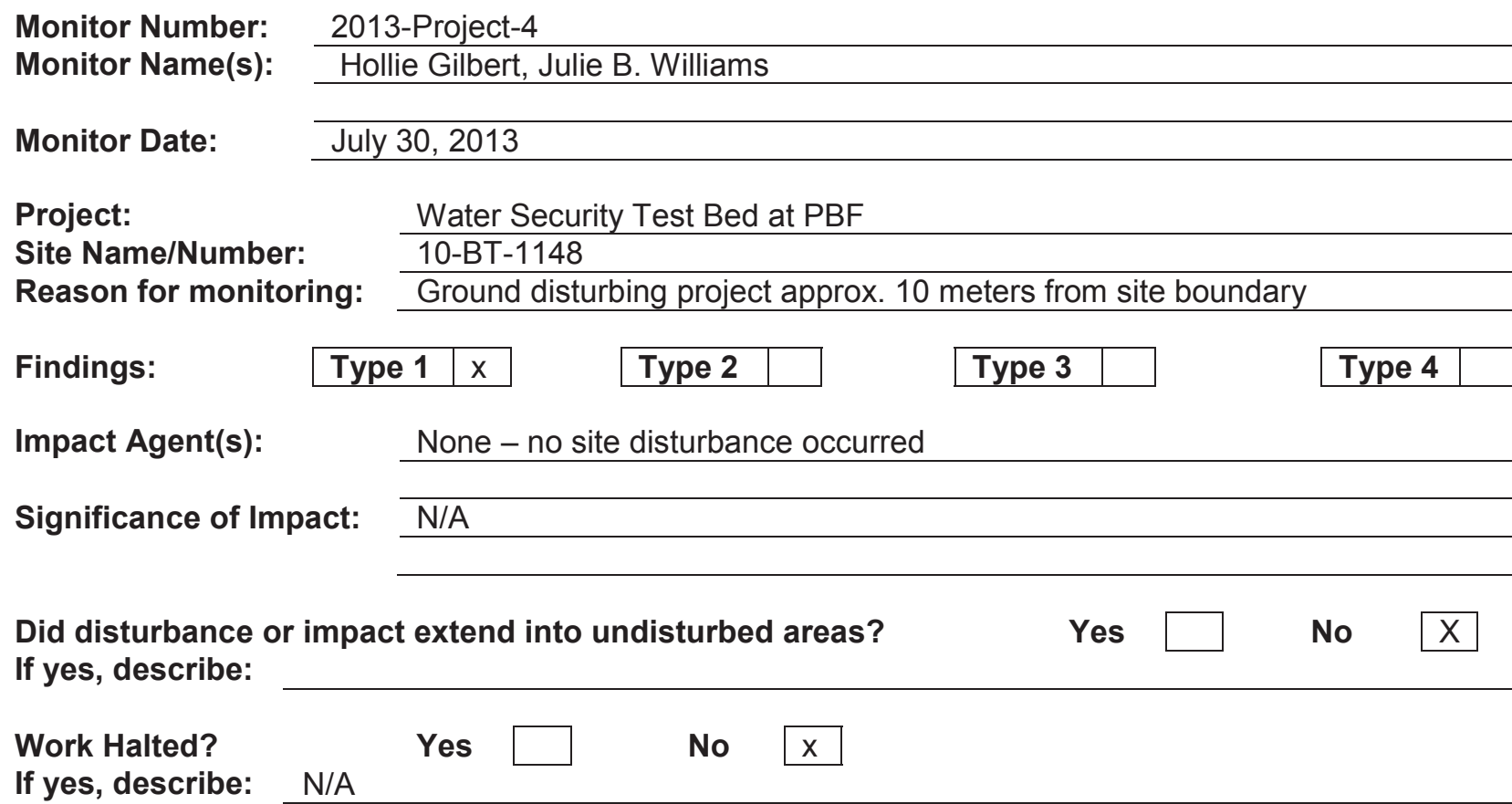

\begin{tabular}{lll} 
Cultural Materials collected? & Yes \\
If yes, describe: & N/A & No $\quad \mathrm{x}$ \\
\hline
\end{tabular}

General Comments: Site was re-located and artifacts flagged for project avoidance. Site was not disturbed during ground disturbance.

Recommendations: None 
$\begin{array}{ll}\text { Monitor Number: } & \text { 2013-Project (PBF/CITRC)-5 } \\ \text { Monitor Name(s): } & \text { Brenda Pace } \\ \text { Monitor Date: } & \text { April 2, 2013 } \\ \end{array}$

Project: $\quad$ Ground disturbance at PBF/CITRC -- National and Homeland Security temporary wireless equipment installation

Site Name/Number: $\quad$ PBF/CITRC area in vicinity of 10-BT-2046

Reason for monitoring: Routine monitoring of ground disturbance in the PBF/CITRC area where Native American human remains have been discovered per LWP-8000 and MCP-3480.

\begin{tabular}{|c|c|c|c|c|}
\hline Findings: & Type 1 & Type 2 & Type 3 & Type 4 \\
\hline
\end{tabular}

Impact Agent(s): Significance of Impact:
Shallow manual excavation $(\sim 2 \times 2 \times 2 \mathrm{ft})$, foot traffic

Hole will house temporary wireless experiment for short term experiment. Researchers will walk from temporary equipment to existing building approximately 100 meters to the west. Sensitive area (stormwater pond) where human remains are preserved is located more than $100 \mathrm{~m}$ to the northwest. No impacts occurred to these materials during the project.

Did disturbance or impact extend into undisturbed areas?

Yes

No $x$ avoided by all activities.

Work Halted? Yes $\square$ No $x$

If yes, describe: Project is in compliance with recommendations for cultural resource protection.

Notifications: $\quad$ None required under Type I finding.

Primary Contact(s):

Date(s) Contacted:

Contact Method(s): | E-mail $\square$ Phone $\square$ Official correspondence, CCN\#:

Cultural Materials observed? Yes $\square$ No $x$

If yes, describe: $\quad$ No sensitive cultural materials or human remains were observed in the shallow excavation and all known sensitive areas were avoided.

Cultural Materials Collected? Yes $\square$ No $\mathrm{X}$

If yes, describe: N/A

General Comments: Required notifications to INL CRM for ground disturbance at PBF/CITRC appear to be working properly. Activity levels remain high for non-ground-disturbing projects, including pedestrian access to undeveloped field areas. Researchers are curious about INL archaeology.

Recommendations: $\quad$ Continue monitoring of all ground disturbance in this sensitive area. Continue to implement required reading on cultural resource sensitivity and protection for all workers.

Attach additional documentation, as warranted (photos, profiles, etc.) Yes No $x$ If yes, describe: 


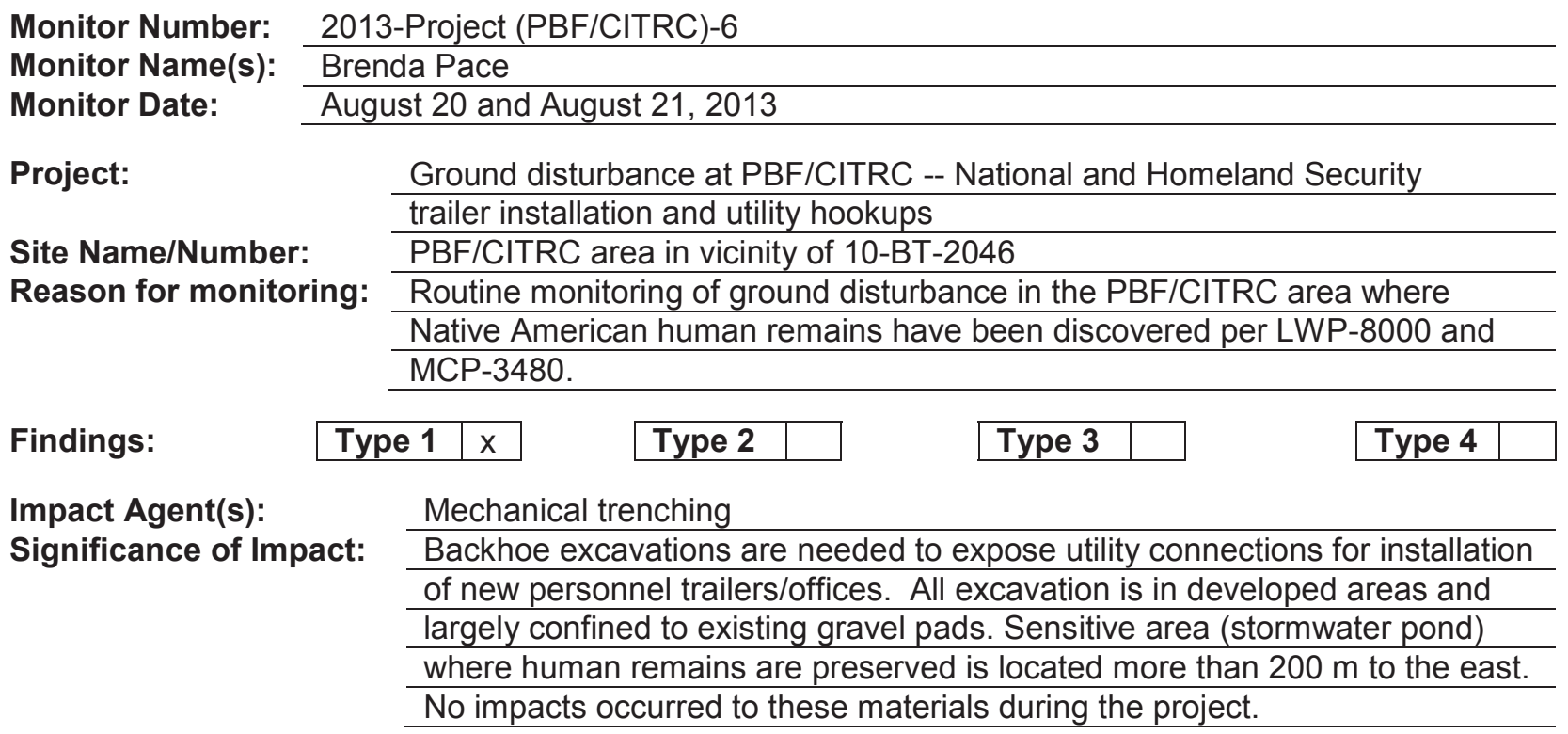

Did disturbance or impact extend into undisturbed areas?

Yes $\square$ No $x$

If yes, describe: Sensitive area (stormwater pond) where human remains were originally found was avoided by all activities.

Work Halted?

Yes $\square$ No $x$

If yes, describe: Project is in compliance with recommendations for cultural resource protection.

Notifications: $\quad$ None required under Type I finding.

Primary Contact(s):

Date(s) Contacted:

Contact Method(s): $\mid \overline{\text { E-mail }} \square$ Phone $\square$ Official correspondence, CCN\#:

Cultural Materials observed? Yes $\square$ No $x$

If yes, describe: $\quad$ No sensitive cultural materials or human remains were observed in the trenches and all known sensitive areas were avoided. Sandy soils were exposed beneath the old gravel pads.

\begin{tabular}{llll} 
Cultural Materials Collected? & Yes \\
& & No & $\mathrm{x}$ \\
\hline
\end{tabular}

If yes, describe: N/A

General Comments: Required notifications to INL CRM for ground disturbance at PBF/CITRC appear

to be working properly. Activity levels remain high for non-ground-disturbing projects, including pedestrian access to undeveloped field areas. Researchers are curious about INL archaeology.

Recommendations: $\quad$ Continue monitoring of all ground disturbance in this sensitive area. Continue to implement required reading on cultural resource sensitivity and protection for all workers.

Attach additional documentation, as warranted (photos, profiles, etc.) Yes No $x$ If yes, describe: 
Monitor Number:
Monitor Name(s):
Monitor Date:

Project:

Site Name/Number: Reason for monitoring:

2013-Project (PBF/CITRC)-7

Hollie Gilbert, Julie B. Williams

July 30, July 31, August 22, 2013
Ground disturbance at PBF/CITRC -- National and Homeland Security Water Security Test Bed project PBF/CITRC area in vicinity of 10-BT-1991

Routine monitoring of ground disturbance in the PBF/CITRC area where Native American human remains have been discovered per LWP-8000 and MCP-3480.

Findings:

\begin{tabular}{|l|l|}
\hline Type 1 & $x$ \\
\hline
\end{tabular}

Type 2

Type 3

Type 4

Impact Agent(s): $\quad$ Mechanical excavation of old berm and removal of old water lines for use in water security test bed project

Significance of Impact: $\quad$ Mechanical excavations are needed to expose and retrieve old water line pipes for use in new water security project. All excavation is along gravel and soil berm that was originally placed over these old pipes. Activity is near discovery point of Native American human remains in the fill of subsurface water line trenches that connected to the nearby blue water tank. No sensitive remains were observed during excavation of the berm.

Did disturbance or impact extend into undisturbed areas?

If yes, describe: N/A
No

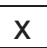

Work Halted?

Yes $\square$ No $\mathrm{x}$

If yes, describe: Project is in compliance with recommendations for cultural resource protection.

Notifications: $\quad$ None required under Type I finding.

Primary Contact(s):

Date(s) Contacted:

Contact Method(s): | E-mail $\square$ Phone $\square$ Official correspondence, CCN\#:

Cultural Materials observed? Yes $\square$ No $\mathrm{x}$

If yes, describe: $\quad$ No sensitive cultural materials or human remains were observed in the berm or in the soil fill around the old water lines.
Cultural Materials Collected?
Yes
No $x$

If yes, describe: N/A

General Comments: Required notifications to INL CRM for ground disturbance at PBF/CITRC appear to be working properly. Activity levels remain high for non-ground-disturbing projects, including pedestrian access to undeveloped field areas. Researchers are curious about INL archaeology.
Recommendations: Continue monitoring of all ground disturbance in this sensitive areas. Continue to implement required reading on cultural resource sensitivity and protection for all workers.

Attach additional documentation, as warranted (photos, profiles, etc.) Yes No $x$ If yes, describe: 